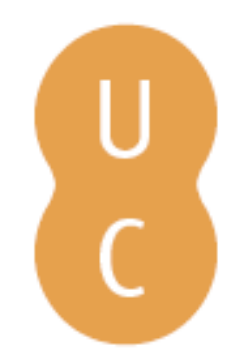

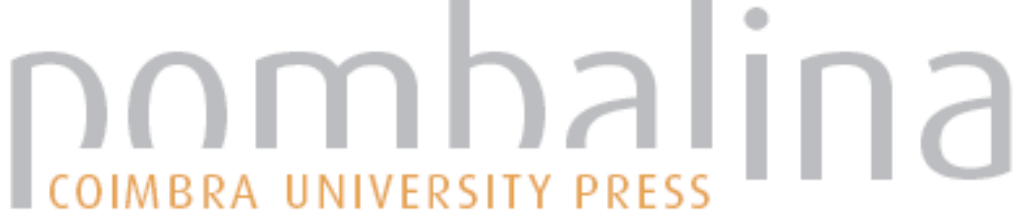

\section{Erasmo e os ciceronianos}

Autor(es): $\quad$ Sartorelli, Elaine Cristine

Publicado por: Imprensa da Universidade de Coimbra

URL

persistente: URI:http://hdl.handle.net/10316.2/45205

DOI: $\quad$ DOl:https://doi.org/10.14195/978-989-26-1671-1_7

Accessed : $\quad$ 26-Apr-2023 14:07:04

A navegação consulta e descarregamento dos títulos inseridos nas Bibliotecas Digitais UC Digitalis, UC Pombalina e UC Impactum, pressupõem a aceitação plena e sem reservas dos Termos e Condições de Uso destas Bibliotecas Digitais, disponíveis em https://digitalis.uc.pt/pt-pt/termos.

Conforme exposto nos referidos Termos e Condições de Uso, o descarregamento de títulos de acesso restrito requer uma licença válida de autorização devendo o utilizador aceder ao(s) documento(s) a partir de um endereço de IP da instituição detentora da supramencionada licença.

Ao utilizador é apenas permitido o descarregamento para uso pessoal, pelo que o emprego do(s) título(s) descarregado(s) para outro fim, designadamente comercial, carece de autorização do respetivo autor ou editor da obra.

Na medida em que todas as obras da UC Digitalis se encontram protegidas pelo Código do Direito de Autor e Direitos Conexos e demais legislação aplicável, toda a cópia, parcial ou total, deste documento, nos casos em que é legalmente admitida, deverá conter ou fazer-se acompanhar por este aviso.

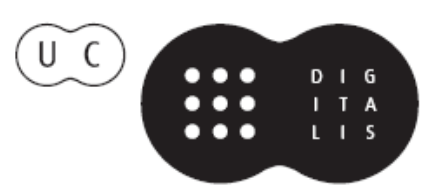




\section{Cícero: \\ obra e recepção}

Isabella Tardin Cardoso, Marcos Martinho (coords.) 


\title{
Erasmo e os Ciceronianos
}

(Erasmus and the Ciceronians)

\author{
Elaine Cristine Sartorelli (ecsart@usp.br) \\ Universidade de São Paulo
}

\begin{abstract}
Resumo: No presente estudo, pretendemos comentar e analisar a posição de Erasmo de Rotterdam (c. 1466-1536) na polêmica conhecida como controvérsia ciceroniana, a qual ele explicitou no tratado satírico Diálogo Ciceroniano. O cerne dessa discussão diz respeito ao conceito de imitatio, uma vez que se poderia reduzir a questão à imitação de um único modelo, Cícero, ou à possibilidade de se recorrer a múltiplos modelos de acordo com o tema, o público, as circunstâncias, mas também, e especialmente, de acordo com o orador.
\end{abstract}

Palavras-Chave: recepção de Cícero; controvérsias acerca da imitação de Cícero; Erasmo.

Abstract: This paper aims to comment on and analyze the position of Erasmus of Rotterdam (1466-1536) in the polemics known as Ciceronian controversies, which he made explicit in his satirical treatise The Ciceronian Dialogue. The central point of this debate concerns the concept of imitatio, thus we could reduce the issue to the matter of imitating only Cicero or multiple models depending on the subject, the audience and the circumstances, but also, and mostly, according to the orator.

KeYwords: reception of Cicero; controversies over the imitation of Cicero; Erasmus.

Quando, por volta de 1485, Paolo Cortesi enviou a seu mentor Angelo Poliziano um conjunto de cartas escritas ciceroniano more, dando início a uma polêmica que viria a ser a mais importante controvérsia literária do século XVI, fazia já quase dois séculos que Dante havia redigido De vulgari eloquentia, sua defesa do emprego da língua vernácula - a "língua vulgar" que ele próprio viria a usar em sua obra-prima, $A$ Divina Comédia. Naquele momento, a opção de escrever sobre temas sérios em "língua vulgar" podia ser considerada uma tentativa de aviltar ou corromper o elevado, na medida em que rompia a milenar tradição do latim como língua escrita, em monastérios e universidades, e possibilitava que a literatura se tornasse acessível para pessoas sem educação formal, ou seja, incapazes de compreender o latim. Da mesma forma, traduzir do latim para as línguas vernáculas, como o fizera, por exemplo, Andrea da Grosseto, podia ser visto não apenas como uma tentativa de modificar a obra literária, rebaixando-a, como também de alterar a forma como esta havia sido herdada e transmitida. Para os detratores desse longo processo de apropriação da cultura clássica, chamado volgarizzamento, "a tradução para o vernáculo não apenas muda a roupa linguística, como os filólogos a chamam (veste linguistica); 
também convida à correção, à interpolação e à abreviação"1, o que ocorre no "mais inculto condutor de mulas", mas também no "mais cuidadoso tradutor de Lívio" (Cornish, 2011, p. 43). A ideia subjacente aqui é a de que a língua falada é regida apenas pelo volgo, isto é, pelo uso e pelo costume, "trabalho contínuo de uma multidão amorfa e anônima” (ibidem) sem os artifícios técnicos necessários à literatura, que pertenceriam tão somente aos docti.

Assim, Giovanni del Virgilio enviou a Dante, então em Ravenna, uma carta em latim escrita em hexâmetros, em que acusava o poeta de "lançar pérolas aos porcos" e de escrever sobre o destino da alma humana em linguagem compreensível para os iletrados, de forma que seu poema era "grunhido" nas esquinas por bufões (Ruud, 2008, p. 281). O próprio Petrarca virá a lamentar que o autor da Divina Comédia fosse conhecido "entre os ignorantes (ydiotas), nas tavernas e nas praças” (Braida \& Calè, 2007, p. 20). Franco Sachetti (1335-1400), em suas Trecentonovelle, também escreve historietas sobre o eccelentissimo poeta volgare, em que as personagens principais são o próprio Dante, um condutor de burros e um ferreiro que recitam seus versos ${ }^{2}$. Aparentemente, o ciclo de associações que permitem ligar o cômico aos gêneros baixos e aos "homens inferiores" autorizou também a conversão de Dante, poeta "vulgar", em personagem de comédia.

De qualquer forma, Dante, ao tratar de tema elevado em outra língua que não o latim, fez algo que elevava seu dialeto florentino à condição de língua literária legitimada. O mesmo seria realizado pelo próprio Petrarca e por Boccaccio, os quais, por sua vez, autorizavam outros a abandonar o latim como único idioma "oficial" da alta cultura, em um movimento análogo a algo que o próprio Cícero havia feito, em latim, com relação ao grego. Escrita, a língua vulgar não deixava, porém, de imitar os modelos latinos. Esse processo durou séculos. Em um tratado publicado no mesmo ano que o Ciceroniano, 1528, Il libro del cortigiano, Baldasare Castiglione buscava apresentar um cortesão formado nos moldes do orador tal como proposto por Cícero. E uma de suas tarefas era falar toscano, nostra lingua propria, com elegância à maneira da Antiguidade, embora consciente de que o registro escrito desta era uma cosa nuova.

A utilização do vernáculo para fins sublimes, antes restritos ao latim, não se devia portanto ao desconhecimento da língua latina, a qual, em lugar de perder importância com a emergência das letras vernáculas, viveu um momento de

\footnotetext{
${ }^{1}$ Todas as traduções citadas neste trabalho são de autoria e responsabilidade da autora.

${ }^{2} \mathrm{Na}$ novela 114, Dante ouve um ferreiro que recita seu poema "smozzicando e appicando" (algo como "cortando e apagando", ou seja, com alterações), o que foi sentido pelo poeta como "grandíssima ingiuria" (Wickesteed \& Gardner, 1902, p. 213). O poeta então joga para cima as ferramentas do ferreiro, com o argumento de que, assim como este não respeitou seus versos, ele tampouco tem obrigação de respeitar o trabalho daquele. Na novela 115 , um condutor de mulas recita Dante enquanto trabalha, mas, durante a recitação, vê-se obrigado a dar seu grito de estímulo para fazer o burro andar, ao que Dante protesta que essa interjeição não está em seu poema...
} 
apogeu nos séculos XV e XVI, com a redescoberta e a crescente popularização dos autores antigos. Em países como a Itália (e especialmente na Itália), tratava-se, de um lado, de imitar modelos romanos da Antiguidade em línguas faladas, como o florentino e o toscano, dando-lhes o estatuto de idiomas autorizados a expressar quaisquer temas, mesmo os elevados, por escrito; e, de outro, e sendo assim, o latim foi mantido como uma espécie de língua de aparato, absolutamente literária, cujo manuseio elegante segundo os padrões do orator ciceroniano era visto como critério legitimador de um bom humanista. Entre estes, havia alguns para os quais o modelo eleito não apenas como o melhor, mas como o único, foi Cícero. E, dessa forma, a assim chamada corrente ciceroniana fez do latim uma língua imprópria para a utilização cotidiana, reservando-a apenas para aqueles temas de que Túlio teria se ocupado. Esses italianos, que se julgavam herdeiros de Cícero e do latim por direito de nascimento, pareciam manter a língua latina da mesma forma como guardavam as joias da família, para ostentação em ocasiões de gala, como marcas de uma especial distinção cultural e social.

Mas havia também aqueles, igualmente doutos e versados em gramática latina, que, por praticarem gêneros literários cujos modelos podiam ser Sêneca ou Virgílio, não se atinham unicamente a Cícero. Entre estes, havia aqueles que, porque escreviam absolutamente tudo em latim, como vivíssima língua de comunicação, usavam o idioma em todos os seus registros, com um vocabulário que forçosamente tinha de dar conta da realidade da época. Nesse sentido, esses últimos, humanistas críticos do escolasticismo, davam, no entanto, continuidade à prática escolástica de considerar o latim como a língua veicular universal (tão universal quanto a cristandade) e absolutamente viva. Entre eles, estava Erasmo de Rotterdam, que, oriundo de um lugar com pouca ou nenhuma tradição escrita em vernáculo, percorreu meia Europa como cidadão do mundo, ensinando a urbanitas e zombando de nacionalismos.

A questão se apresenta assim, pois: um humanista como Bembo escreve em toscano, reservando o latim para os temas da alta cultura, nos quais pode se permitir imitar Cícero para demonstrar sua destreza gramatical diante de outros homens igualmente doutos e versados; um autor como este escolhe o latim com a finalidade de exibir sua perícia e sua cultura para seus pares. Erasmo, por outro lado, escreve apenas e tão somente em latim sobre qualquer assunto e, por isso, vê-se na circunstância de ter de "rebaixar" a língua a fim de tratar de temas comezinhos e cotidianos e também da matéria cristã.

Enquanto isso, o latim continuava ainda a ser a língua veicular por excelência da teologia e da filosofia (ainda não separadas), bem como das ciências. Mas também aqui as línguas vernáculas já fazem sua aparição, como atesta, por exemplo, Tobias Adami, editor de Campanella. No Prefácio à Apologia de Galileu, Adami menciona uma carta endereçada a Sebastiano Fantoni "escrita em italiano e impressa em Nápoles” por Lazzaro Scoriggio, a qual, "se tivesse sido 
traduzida para o latim, poderia servir de apêndice a este tratado" ${ }^{3}$. Se esse passo denuncia que o latim era, e seria ainda por muito tempo, o idioma oficial das ciências, mostra também, por outro lado, que já havia produção acadêmica em língua "vulgar". Da mesma forma, a Reforma trouxe uma intensa produção de teologia em alemão, e, pouco mais tarde, Calvino virá a editar seus livros em latim e em francês. Ao latim restava então, como o próprio Erasmo aparentemente já o havia percebido com desgosto, ser a língua internacional da correspondência dos humanistas, bem como de suas polêmicas.

\section{A controvérsia CiCERONIANA}

Foi toda em latim, e sobre a imitação de modelos latinos, que se desenvolveu a chamada "controvérsia ciceroniana", a qual mobilizou os grandes nomes do humanismo do final do século XV ao XVI. Tratava-se, em linhas gerais, de um debate que colocou em lados opostos dois tipos de admiradores de Cícero: os estritos e os ecléticos.

Os primeiros elegeram Marco Túlio como o único modelo digno de ser imitado e, quando escreviam em latim, tentavam fazê-lo restringindo-se ao vocabulário do Arpinate, quase como se copiassem fragmentos das sentenças ciceronianas como decalques, a fim de carimbá-las em seu próprio discurso. Assim, esforçavam-se por reconstituir por vezes no púlpito papal, o esplendor do latim forense e judiciário romano. Como prescreviam a prática de uma imitação que poderia chegar a ser a reprodução ipsis litteris de excertos de um modelo único, Cícero ${ }^{4}$, quaisquer palavras ou construções sintáticas que não pudessem ser encontradas nos discursos de Túlio, incluindo-se os vocábulos surgidos após sua morte, não eram permitidas por eles. Isso certamente significava que quaisquer temas que tenham escapado ao orador romano simplesmente não poderiam ser tratados por eles em latim. Erasmo usará de toda sua ironia contra essa interdição que vetava o uso de todo o léxico cristão, embora os ciceronianos fossem, em grande parte, membros do clero.

Do outro lado do debate, estavam os partidários da imitação composta, para os quais a ideia de imitatio se vinculava ao estudo de vários modelos, assimilados e reelaborados segundo o decorum exigido pelo tema; entendiam-na, pois, como a possibilidade de extrair as virtudes de cada um dos melhores escritores, e até contemplavam a possibilidade de superá-los. Assim, o locus communis

${ }^{3}$ F. Thomae Campanellae. Apologia pro Galileo, ubi disquiritur utrum ratio philosophandi quam Galileus celebrat, faueat sacris scripturis an aduersetur. Impensis G. Tampachii, 1622. Uma tradução desta obra para o português, desta pesquisadora, encontra-se no prelo.

${ }^{4} \mathrm{Em}$ Roma, acabaria mesmo por chegar-se à fundação de uma sociedade de literati cujo propósito era o de que seus membros fizessem o voto de jamais usar qualquer palavra que não pudesse ser encontrada em Cícero. Para isso, conta-se (Scott, 1910, p. 22) que seu líder, Pietro Bembo, carregava "quarenta port-folios" com citações extraídas de Cícero, e apenas de Cícero. 
do imitador eclético no Renascimento é a comparação do trabalho do imitador com aquele realizado pela abelha. Como esta, aquele recolhe o pólen de diversas flores para, em seguida, digerir esse material variado a fim de produzir o mel, ou seja, obter um resultado diferente de cada um dos ingredientes de que fora formado, melhor que eles. Mesmo estes, no entanto, fazem constantemente a ressalva de que Cícero deveria continuar ainda a ocupar o primeiro posto dentre os melhores modelos.

Já em Petrarca, um dos "descobridores" de Cícero (no sentido de que resgatou textos do orador romano que haviam permanecido desconhecidos ao longo do período a que os humanistas chamarão Medium Aevum), pode-se encontrar algo que mais tarde viria a alimentar a controvérsia. Embora tenha sido um dos mais ardorosos admiradores do orador romano, Petrarca não deixou, no entanto, de recorrer, em termos senequianos, à metáfora da abelha (Fam. 22:2; 23:19), bem como a outra, que virá a se tornar igualmente recorrente, segundo a qual uma obra deve se assemelhar a seu modelo como um filho que saiu ao pai, mas não como o retrato se parece com o retratado (Fam. 23:19). Ele elogia e busca, pois, não uma reprodução idêntica (identitas), mas a semelhança (similitudo), a qual tampouco deve ser excessiva (non nimia). A imitação deve fazer aparecer "a luz do talento brilhante do seguidor" (sequacis lux ingenii emineat), não sua "cegueira ou pobreza" (non cecitas aut paupertas). Por esses pequenos excertos, já se pode depreender que a prática da imitatio não se confundia com a tentativa de uma cópia servil, e, de qualquer forma, jamais de uma imitação exclusiva de Cícero.

Já outro apaixonado seguidor de Cícero ainda no século XIV foi Collucio Salutati, o primeiro a usar um estilo tão minuciosamente colado àquele do orador romano que, segundo seu contemporâneo Filippo Villani (in Scott, 1910, p. 8), poderia "com razão" ser chamado de "símio de Cícero" (Ciceronis simia merito dici possit). Na virada do século XV, surgiu também talvez a primeira autoridade ${ }^{5}$ em Cícero, Gasparino Barzizza.

Nessa época, deu-se a recuperação completa de vários textos de Cícero, dentre os quais o De Oratore (talvez o primeiro livro impresso na Itália, em 1465) e o Brutus. E assim, progressivamente, o ideal de orador moderno, em deliberada contraposição ao cânone escolástico, foi se aproximando da figura de um imitador capaz de reproduzir Cícero - quanto ao espírito, se possível, mas obrigatoriamente quanto à letra.

Ainda em meados do século XV deu-se um famoso debate entre Lorenzo Valla e Poggio Bracciolini. Essa importante discussão literária, que tratou

5 "A textual scholar and Ciceronian expert", segundo R.G.G. Mercer, The Teaching of Gasparino Barzizza, with special reference to his place in Paduan Humanism. London: The Modern Humanities Research Association, 1979. 
especialmente de imitação, talvez tenha ficado eclipsada pela aparência de bate-boca gerada pelas acusações e mesmo insultos pessoais entre ambos. Poggio, que se encaminhava para a tendência crescente do ciceronianismo, se tornou

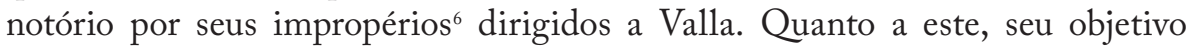
declarado era exaltar Quintiliano (Scott, 1908, p. 10).

Mas o tema veio a se transformar realmente em polêmica com a curta mas fundamental correspondência entre o grande humanista Angelo Poliziano e seu então discípulo Paolo Cortesi, naquela que foi chamada "a primeira batalha do ciceronianismo” (Mañas Nuñez, 2009, p. 23). Tudo começou quando Cortesi enviou ao seu mestre um presente que julgava valiosíssimo: uma seleção de cartas escritas por diversos autores nas quais, acreditava, encontrava-se o mais puro estilo ciceroniano. Com essa coletânea em mãos, Poliziano redigiu uma resposta "curta e bastante descortês" (Dellaneva, 2007, p. vii), em que criticava a superstitio em que a imitação de Cícero se transformara. Os autores das cartas que Cortesi lhe enviara lhe parecem ser "semelhantes ao papagaio ou à gralha, proferindo coisas que não entendem" (similes esse uel psitaco uel picae uidentur, proferentibus quae nec intelligunt) ${ }^{7}$. Dizendo-se envergonhado por ter perdido seu tempo com a leitura dessas cartas (epistolas in quibus legendis pudet bonas horas male collocasse), afirmava que elas "carecem de forças e de vida; carecem de atitude, carecem de sentimento, carecem de caráter; deitam, dormem, roncam" (carent uiribus et uita; carent actu, carent affectu, carent indole; iacent, dormiunt, stertunt). Dizia ainda que não havia ali "nada verdadeiro, nada sólido, nada eficaz" (nibil ibi uerum, nibil solidum, nibil efficax), e que seus autores são homens que "mendigam um estilo bocadinho por bocadinho, como se fosse pão" (stillum quasi panem frustillatim mendicant) e cujo discurso é "sempre trêmulo, vacilante, instável, claramente mal preparado, mal cultivado" (oratio semper tremula, vacillans, infirma, videlicit male curata, male pasta). E, já que os ciceronianos faziam tanta questão de imitar os traços ou feições de Cícero, Poliziano lhes recorda que "a face de um touro ou a de um leão" lhe parecem "de longe mais respeitáveis do que a do macaco, a qual, no entanto, é a mais semelhante à do homem" (mibi uero longe honestior tauri facies aut item leonis quam simiae uidetur, quae tamen homini similior est)...

A réplica, a que Poliziano nem respondeu, foi, por sua vez, uma longa defesa da imitação nos moldes ciceronianos. E, embora Cortesi diga que deseja se parecer com seu modelo "não como um macaco com um homem, mas como um filho com o pai" (similem volo non ut simiam hominis, sed ut flium parentis), reitera que, ainda assim, prefere ser "assecla e macaco de Cícero a ser aluno ou

\footnotetext{
${ }^{6}$ Em carta a Van Dorp, em defesa do seu Elogio da Loucura, Erasmo se queixa de que reclamam apenas da sua Stultitia, enquanto "outros, como Poggio, escreveram coisas ímpias, sujas e pestilentas" (impia, spurca, pestifera).

${ }^{7}$ Todas as traduções de excertos das controvérsias foram feitas a partir da edição bilíngue de Dellaneva (2007).
} 
filho de outros" (assecula et simia Ciceronis quam alumnus aut filius aliorum). Com relação à imitação composta, formada a partir de vários modelos, esta tem, em sua opinião, "um não sei quê de monstruoso" (nescio quid monstruosum), e seu resultado é como a ingestão de "vários tipos de comida" (varia ciborum genera) ao mesmo tempo: "dá má digestão" (male concoquantur).

Já no XVI, o debate prosseguiu com Gianfrancesco Pico della Mirandola e Pietro Bembo. O platônico Pico recorreu à Ideia da Beleza para defender a imitação composta: se ela está em toda parte, deve, por conseguinte, ser buscada em todos os autores. Afirma que "todos os bons escritores deveriam ser imitados" (imitandum inquam bonos omnes), "não apenas um único em tudo" (non unum aliquem nec omnibus etiam in rebus). Critica ainda os tecnicismos mecânicos dos ciceronianos e defende a busca pela aemulatio, ou seja, a superação dos modelos.

Bembo, que, apesar de cardeal e secretário papal, foi o maior nome do movimento ciceroniano, responde dizendo que nem precisaria ter se dado o trabalho de redigir uma réplica, uma vez que, para conhecer sua posição, lhe bastaria ter lido "a bela, arguta e séria carta de Paolo Cortesi, com a qual ele quebrou a leviandade do não muito prudente Poliziano" (epistolam bellam et cum argutulam tum etiam gravem, qua is Politiani non multum prudentis levitatem fregit). Afirma ainda que sequer entende (non intellego) por que se deveria imitar "não um autor em particular, mas todos os bons" (non unum aliquem sed omnes bonos). Para ele, ou não se imita absolutamente, ou, se é preciso fazê-lo, melhor voltar-se não para o bom, "mas apenas para aquilo que nós consideramos o melhor e o mais perfeito" (sed ad illa tantummodo quae optima quaeque perfectissima haberentur).

Quanto à Ideia platônica, Bembo só pode dizer que, tendo vasculhado sua alma, não viu "nenhuma forma de estilo nela, nenhum modelo de discurso" (nullam in eo stili formam, nullum dictandi simulachrum); se ele obteve algum, ele o desenvolveu por si mesmo, "por meio de muitos labores, prática e exercício" (multis laboribus ac longo usu exercitationeque). Aqueles a quem a capacidade de aprimorar-se foi negada, estes nem deveriam tentar imitar, mas "aqueles que quiserem se aprimorar tanto quanto possível, estes não deveriam ser estimulados a seguir senão o melhor modelo" (neque non ad optimum, qui quo libuerit si volent progredientur, sunt incitandi). Ademais, acaba por admitir que sua concepção de imitatio se restringe a "transferir a semelhança do estilo de um outro a seus próprios escritos" (imitari nisi alieni stili similitudinem transferre in tua scripta). $\mathrm{O}$ que o imitador deve procurar apreender em seu modelo é, portanto, aquilo que se revela exteriormente, na aparência. E, sendo assim, que pode haver de mais absurdo que perseguir muitas "diferentes formas de escrever" (scribendi formas diversas)? Isso seria como construir um edifício em que, em cada lado, fossem representados "muitos exemplos das várias formas de projeto e realização" (multa exempla variarum imaginum atque operum). Dessa forma, quem quer que deseje imitar vários autores ao mesmo tempo falhará em tirar proveito de qualquer um deles. A abundância (copia) "distrai a mente e os sentidos e não permite que a 
alma se concentre" (distrahit mentem atque sensum, neque haerere animum sinit):

Neque qui alium post alium aggreditur, ei quam in uno curam intenderit, non in alio saepe remittere necesse est. [...] Accedit eodem scriptorium diversitas et dissimilitudo. [...] Horum cum imitari alterum didicerimus, alterum doceri aggrediamur, reiicere multa cogimur corum quae paulo ante summa industria, summo nostro labore sumus consecuti. Quamobrem frangitur studium, debilitatur diligentia, contentio illa nostra ardorque omnis animorum elanguescit atque restinguitur, dum buc illuc tamquam a fluctibus, sic in exemplorum varietate iactamur ${ }^{8}$.

E esse modelo único, para Bembo, é Cícero, pois seria absurdo confiar que alguém possa encontrar um caminho que seja melhor que aquele que o Arpinate "não tanto encontrou, realmente, quanto tornou mais grandioso e ilustre" (non tam quidem invenit ipse, quam ab illis inventam ampliorem et illustriorem reddidit). Além de sua defesa da imitação unicamente de Cícero, Bembo protagoniza indireta e involuntariamente os debates na contenda ciceroniana também por outro motivo. É que seu discípulo, o "ciceronianíssimo" Christophe Longueil, teria sido o principal inspirador da personagem principal do Dialogus Ciceronianus de Erasmo, tema deste texto e que estudaremos a seguir ${ }^{9}$.

\section{Erasmo e os CicERonianos}

Uma das acusações mais frequentes dirigidas a Erasmo nas polêmicas literárias em que se envolveu foi a de publicar de forma apressada e descuidada, sem revisão. Além do famoso trocadilho com as palavras batavus e barbarus, seus detratores romanos diziam-lhe Erras mus... No tratado De recta pronuntiatione, escrito ao mesmo tempo em que redigia o Ciceronianus, Erasmo conta episódios anedóticos de escorregões no latim perpetrados por italianos de que ele teria sido testemunha, e afinal exclama, ironicamente: equidem arbitrabar nos solos barbaros

${ }^{8} \mathrm{E}$ é forçoso que aquele que passa de um (modelo) a outro frequentemente não conceda a um a atenção que estiver prestando em outro. [...] A isso contribui a diversidade e dessemelhança entre escritores. [...] Quando, tendo aprendido a imitar um deles, começamos a ser ensinados a imitar outro, somos forçados a rejeitar muito daquilo que um pouco antes perseguíamos com o maior empenho e com o maior esforço de nossa parte. Eis por que nosso entusiasmo se quebra, nossa diligência se enfraquece, aquela nossa importante concentração e todo ardor de nossos espíritos tremulam e apagam-se, enquanto somos atirados de um lado para o outro, como que por ondas, na variedade dos modelos. Traduzido pela autora a partir da edição bilíngue de Dellaneva (2007).

${ }^{9}$ Com relação à "terceira batalha do ciceronianismo", que se desenvolveu cerca de vinte anos depois, na correspondência trocada em 1532 entre Giambattista Giraldi Cinzio e Celio Calcagnini, esta não será tema deste estudo, por ter ocorrido em data posterior à intervenção de Erasmo, parte central do presente trabalho. Da mesma forma, as refutações em regra que Erasmo recebeu de Etienne Dolet e de Julius Scaliger são objeto de uma investigação que esta pesquisadora vem realizando desde seu estágio de pós doutoramento na Université BordeauxMontaigne, em 2015. 
sonare barbare!... Pela frequência com que se refere a esse insulto, é possível mesurar o quanto este havia atingido o holandês, autor de um Antibarbarorum liber que defendia precisamente o estudo dos autores clássicos e das línguas antigas e chamava barbari aos escolásticos e aos inimigos da cultura humanística e das línguas clássicas. Para seus adversários, porém, era Erasmo que agia como os escolásticos, ao violar a língua latina com o jargão próprio da religião e com palavras inexistentes em Cícero.

Erasmo estava ciente de que, "por causa de Lutero" (Lutheri causa), havia uma desconfiança entre os romanos para com tudo aquilo que viesse no norte. Por isso, algo que parece tê-lo exasperado ainda mais foi o fato de que o único ciceroniano aceito como tal pelos exigentes italianos foi outro cisalpino, o brabante Christophe de Longueil, conhecido também pelo nome latino Longolius. Segundo todos os indícios, a personagem do monomaníaco Nosópono, cuja enfermidade Erasmo cura em seu tratado dialógico, teria sido inspirada nesse discípulo de Pietro Bembo.

Educado na França, Longueil chegou a Roma por volta de 1517, onde, tendo travado conhecimento com um grupo de ciceronianos liderados por Bembo e Sadoleto, passou a concentrar todos seus estudos e esforços na imitação exclusiva de Cícero. Tão bem ele se saiu nesta tarefa que seus mentores italianos, à maneira de Cícero para com Árquias, decidiram, em 1519, pleitear uma "cidadania romana”, então nada mais que simbólica, para seu protegido. Descobriu-se, no entanto, que, havia muitos anos, ele, então em idade escolar, havia escrito um discurso em que comparava as belezas da Itália às da França, com vantagem para esta última. Isso levantou contra ele uma feroz reação dos italianos adversários da ideia de que a cidadania romana lhe fosse concedida, fato que o obrigou não apenas a compor discursos Ciceroniano more em sua defesa e apresentá-los em uma espécie de tribunal ciceroniano, mas também até mesmo a sair da cidade, ocasião em que chegou a visitar Erasmo em Louvain. Este zombou impiedosamente de todo este episódio, como veremos mais adiante.

Por sua adesão ao círculo dos ciceronianos italianos, Longueil se tornara um crítico de Erasmo. A notícia de uma carta de sua autoria, em que comparava os estilos de Budé e Erasmo, em detrimento deste, chegou aos ouvidos do holandês, que chegou a lhe enviar uma resposta, revelando assim que havia tomado conhecimento de tal correspondência. Segundo Levi (1986, p. 325), a réplica de Erasmo tem um tom de "aparente modéstia e cortesia", mas também um "evidente orgulho ferido". Assim, quando Longueil foi a Louvain para conhecer Erasmo pessoalmente, este não pareceu especialmente disposto a se esforçar para agradar ao visitante, seu hóspede por três dias. Quando Longueil morreu logo em seguida, aos 33 anos, Erasmo atribuiu essa morte precoce a seus cuidados obsessivos para com o ciceronianismo, os quais teriam consumido um homem talentoso, mas dominado pela ambição de se destacar com um título, o de ciceroniano, que lhe fosse concedido por "quatro jovens italianos ineptos" ( $a$ 


\section{quattuor ineptis Italis adulescentibus).}

Nos anos seguintes, o holandês, cujo prestígio encontrava-se já em declínio, continuou a cultivar uma posição crescentemente hostil e de antipatia recíproca para com os ciceronianos. Além disso, Reginald Pole publicou, em 1524, uma coletânea póstuma das obras de Longueil, o que aumentou o prestígio do brabante como exemplo maior da eloquência do norte, em lugar do holandês, que, por sua vez, assistia não apenas à diminuição de sua influência por sua recusa em tomar parte na Reforma (ou, por outro lado, por ser responsabilizado por ela), como também à ruína de seu projeto irênico, pacifista, cristão e inteiramente baseado no latim como lingua franca..$^{10}$

Os sofrimentos de Longueil na árdua e impossível busca pela eloquência ciceronia não lhe foram úteis para nada, diz Erasmo... Mas serviram para que ele, Erasmo, compusesse uma de suas inesquecíveis caricaturas, neste tratado satírico considerado o marco definitivo nas controvérsias ciceronianas, uma vez que tanto os debates que o precederam como os posteriores não são estudados senão em relação com ele. Difícil mesmo dizer o que seria da memória desse "ciceronianíssimo" Longueil, não fosse pelo retrato cômico que dele nos deixou seu rival do norte.

\section{O Dialogus Ciceronianus ${ }^{11}$}

Assim, envolvido havia tempos em uma rivalidade com outro não italiano pela excelência no latim e certamente exasperado pelo zelo literário de seus adversários italianos enquanto a Cristandade humanística de que ele foi o representante máximo encontrava-se em perigo, Erasmo decide usar contra eles sua melhor arma, mostrando-os de forma cômica em um tratado satírico. Assim, publica em 1528 o seu Dialogus Ciceronianus, em que apresenta uma caricatura de ciceroniano na tragicômica figura do fanático Nosópono, cujo nome significa "aquele que sofre de uma enfermidade" ${ }^{2}$. Este deseja ser reconhecido como ciceroniano a qualquer preço e, para isso, não mede esforços, ainda que à custa de jejuns e sacrifícios; vivendo como um asceta e tendo para com as palavras de Cícero uma reverência religiosa, Nosópono faz parte de uma secta, a dos ciceronianos pagãos.

Seus interlocutores são dois: Hipólogo, que faz o papel de "escada" no diálogo; e o porta-voz de Erasmo, o polemista Buléforo, "aquele que traz o

\footnotetext{
${ }^{10}$ Para melhor compreensão dos terríveis anos finais da vida do holandês, consultar BarralBaron, Marie. Ĺenfer d'Erasme, L’humaniste chrétien face à l’histoire. Genève : Droz, 2014.

${ }^{11}$ Todas as citações do Ciceroniano são de autoria desta pesquisadora. A tradução completa foi publicada em 2013 pela Unesp e em 2015 pela Levoir, para a Folha de SP.

${ }^{12}$ Levi (1986, p. 287) propõe a tradução de Mr. Workmad para seu nome; uma boa atualização seria, a nosso ver, Workalholic.
} 
conselho”. Este, que se propõe a fazer as vezes de Davus, como na peça Andria de Terêncio, desempenha também um papel análogo àquele que Sócrates representa em um diálogo platônico (Chomarat, 1981, p. 817), uma vez que, por meio de suas perguntas, conduz - ou induz - Nosópono a reconhecer, pouco a pouco, a incongruência de suas posições. Ao mesmo tempo, como na maiêutica, estabelece-se uma cumplicidade entre o filósofo (aqui, Buléforo) e o público leitor contra o sofista que sofre o "interrogatório" (aqui, Nosópono). Essa mesma aliança entre certas personagens e o público, com vistas a corrigir aquele de que se ri pela exclusão e pela irrisão, ocorre na comédia. Essa tarefa fica frequentemente a cargo de Hipólogo, cujas falas trazem tantas vezes lugares-comuns, versos bem conhecidos e truísmos de vários tipos, como os bordões da comédia ou o desfecho da piada.

A primeira parte do diálogo, "pura diversão" (Levi, 1986, p. 327), nos apresenta o ciceroniano Nosópono. Antes "o mais charmoso (lepidissimus) de todos, o mais coradinho (rubicundulus) e gordinho (obesulus), transbordando de encantos e de graças (ueneribus et gratis undique scatens)", agora, por causa de sua doença, mais parece um "fantasma" (larua) que um homem vivo. Sua "aparência e magreza" (facies ac macies) levam a prognosticar "algo de sinistro" (quid sinistri). Mas sua enfermidade não é a hidropsia, nem "esse novo tipo de lepra, o qual o vulgo homenageia hoje em dia com o nome de sarna" (nouum hoc leprae genus, cui uulgus hodie scabiei nomine blanditur), nem a tísica, a tuberculose ou a icterícia; é algo mais profundo, "algo que se alastra a partir das partes mais recônditas da alma, que estão no cérebro" (ab intimis animi penetralibus quae in cerebro sunt proficiscens). É, na verdade, um "novo gênero de mal" (nouum mali genus), que ainda nem tem nome em latim. Esse mal é "antes do coração" (immo cordis), e, para descrevê-lo, Nosópono emprega o vocabulário com que os antigos falavam do pathos amoroso: incurável, seu alívio não pode advir dos médicos ou dos remédios humanos, mas apenas do "recurso de uma divindade" (numinis opus est ope), "a que os gregos chamam Peithó" (diua quae Graecis dicitur Peithó). Essa é "a deusa que subjuga os corações" (dea flexanima), por quem Nosópono se dispõe a morrer, já que o desejo de possuí-la o consome a ponto de tornar sua vida intolerável. Mas o apaixonado acrescenta que o objeto de sua afeição é apenas e tão somente a eloquência ciceroniana; se não tiver sucesso em alcançá-la e em obter o título de ciceroniano, toda a sua vida será “amarga" (acerba). Por isso, Nosópono se esforça ainda para permanecer indiferente aos apelos do corpo e das paixões mundanas, como um asceta. As paixões humanas, ele as vê como tumultos que podem ser "mais incômodos que as forjas e os martelos dos vizinhos" (molestiores esse quam uicinorum fabrorum folles aut malleos); por esse motivo, não permite que sentimentos tais como o amor, o ódio, a inveja, a esperança, o medo e o ciúme o afetem. Por isso também, decidiu manter-se celibatário. Para seu irônico interlocutor, essa foi uma atitude muito sábia... 
Sapuisti, Nosopone. Nam mea coniux, si noctu parem ad istum modum operam dare Ciceroni, perrumperet ostium, laceraret indices, exureret schedas Ciceronem meditantes et, quod his etiam est intolerabilius, dum ego do operam Ciceroni, illa uicarium accerseret, qui ipsi pro me operam daret. Itaque fieret, ut dum ego meditor euadere Ciceroni similis, illa gigneret aliquem Bulephoro dissimilem. ${ }^{13}$ (Cic. 34, 254-256).

De dia, havia já sete anos que Nosópono era incapaz de sequer tocar qualquer livro que não tivesse sido escrito por Marco Túlio, com o mesmo escrúpulo e rigor com que certas ordens religiosas se abstinham de comer carne. De noite, em seus sonhos, não via senão a imagem de Cícero, "homem divino" (diuini uiri), que, em seu calendário, está entre os apóstolos.

Quanto a seu método de trabalho, o ciceroniano conta que organizou três arquivos gigantescos a partir da obra do orador romano: um index alfabético, que apresenta as diversas acepções de cada palavra empregada por Cícero; um segundo volume, que traz a ordem das palavras e as formulae loquendi próprias de Cícero, ou seja, que tropos, figuras, sentenças, lepide dicta e outras deliciae podem ser encontrados em suas obras; e um terceiro livro, consagrado aos incisos, frases e períodos. Tanto cuidado é mais do que necessário, uma vez que, mesmo com um verbo como amo é preciso redobrar o cuidado. É que talvez Cícero tenha empregado amo, amas, amat, mas não amamus, amatis... E, se Cícero não empregou essas formas, elas não devem ser usadas, uma vez que não é lícito usar nenhuma palavra que não tiver sido usada por Cícero...

Nosópono faz suas minuciosas anotações tendo o cuidado de assinalar aquilo que está em Cícero com uma marca vermelha; "o que não está, com uma marca preta” (quae sunt apud Ciceronem, miniata uirgula signo, quae non sunt, atra). Caso um termo, perfeitamente canônico, for encontrado em qualquer outro autor igualmente clássico e paradigmático, ainda assim o ciceroniano se privará de seu uso.

Nulla est exceptio. Ciceronianus non erit, in cuius libris uel una dictiuncula reperiatur, quam non possit in Ciceronis lucubrationibus ostendere totamque phrasim hominis non aliter quam adulterinum numisma reprobam iudicabo, in qua uel unum uerbum resederit, quod Ciceroniani characteris non habeat notam, cui soli uelut eloquentiae principi datum est a superis Romani sermonis monetam cudere. ${ }^{14}$ (Cic. 26, 213-214).

${ }^{13}$ Foste sábio, Nosópono! Pois, se eu começasse a dar atenção a Cícero deste mesmo modo à noite, minha esposa arrombaria a porta, rasgaria os catálogos, queimaria as páginas com meus estudos sobre Cícero e, o que é ainda mais intolerável, enquanto eu estivesse dando atenção a Cícero, ela mandaria vir um substituto que desse atenção a ela em meu lugar. E, assim, ocorreria que, enquanto eu estivesse meditando em ser semelhante a Cícero, ela geraria uma criança nada semelhante a Buléforo...Obs.: todas as citações latinas desta edição foram extraídas da edição digitalizada em 2003 e que consta na plataforma Itinera Electronica: du texte à l’ hypertexte, e seguem, portanto, a paginação desta, tal como pode ser consultada nesse portal por intermédio da Université Catholique de Louvain.

${ }^{14}$ Não há exceção. Não será ciceroniano aquele em cujos livros se encontrar uma única palavrinha que ele não possa apontar nos escritos de Cícero. E julgarei espúrio como uma 
Hipólogo, cuja intervenção se dá nos momentos mais cômicos, finge concordar, argumentando que, "por causa de uma única moedinha falsa, uma grande quantidade de dinheiro é confiscada" (ob unicum nummulum adulterinum ingentem pecuniae uim confiscari) e que, "por causa de uma única verruga, ainda que pequena, toda a beleza de uma moça, por mais notável que seja, perde seu encanto" (uno naeuo, quamlibet exiguo totam puellae formam, licet alias egregiam, deuenustari). Chomarat (1981, p. 817-818) chama a atenção para a ironia da alusão intertextual a um conhecido verso de Horácio (Sat. I, 6, 67), cuja referência não é percebida por Nosópono, que desconhecia o texto aludido precisamente porque só lia Cícero...

Munido de suas anotações, o ciceroniano Nosópono escreve apenas na calada da noite, praticamente escondido num quarto vedado, "com paredes grossas, portas e janelas duplas, com todas as fendas fechadas cuidadosamente com gesso e piche" (densis parietibus, geminis et foribus et fenestris, rimis omnibus gypso piceque diligenter obturatis), para que não entre nenhuma luz ou som, "a menos que seja mais forte, como o é o das brigas das mulheres ou das fundições dos serralheiros" (nisi uehementior, qualis est feminarum rixantium aut fabrorum ferrariorum). Para que o crepitar da madeira da lareira não o atrapalhe, prefere ainda sentar-se para escrever no frio e no escuro. Além disso, pratica o jejum quando se prepara para suas longas vigílias noturnas, ingerindo apenas aquilo que é útil para a memória: "dez bagos de uvas passas pequeninas" (decem acinos unae passae minutulae) e "três sementes de coentro, revestidas de açúcar" (tria coriandri grana saccaro incrustata).

Cercado de tantos cuidados e precauções, o ciceroniano finalmente se dispõe a escrever. Ele mostra como o faz por meio de um exemplo: caso precisasse escrever uma carta a um amigo para pedir de volta alguns livros emprestados, Nosópono passaria a procurar em suas anotações (os três volumes gigantescos!) que palavras, dentre as empregadas por Cícero, poderiam ser usadas ali; em seguida, faria o mesmo com os tropos e figuras, e finalmente os ritmos. Sendo assim, redigiria apenas um período no intervalo de uma noite... Seria preciso então refazer todo o processo pelo menos dez vezes, para não correr o risco de que alguma palavrinha não ciceroniana escapasse. Faria então outra verificação, a de tropos e de fórmulas, e, por último, a dos ritmos e da composição. Depois seria preciso ainda deixar o texto descansar, para que, numa revisão final, não passasse despercebida alguma construção ilegítima, não ciceroniana. Por mais acurada que seja a carta resultante de tantos trabalhos, Buléforo não pode deixar de lembrar que, "nesse meio tempo, outro usufrui dos livros desejados por ti" (interim ille fruitur codicibus abs te desideratis)...

Quanto à preparação de Nosópono para falar, ele mesmo esclarece que "a primeira precaução é não falar latim com ninguém, tanto quanto possa evitá-lo”

moeda falsa todo o estilo de um autor no qual restar uma única palavra que não tiver a marca do carimbo de Cícero. Ele é o único a quem, como príncipe da eloquência, foi dado pelos deuses cunhar a moeda do discurso romano. 
(prima cautio est, ne cui loquar Latine, quod queam effugere). Quando Buléforo lhe replica que "é, de fato, um novo tipo de exercício, se, calando-nos, aprendemos a falar" (nouum autem exercitationis genus, si silendo discimus loqui), Nosópono o justifica com uma resposta que, como veremos oportunamente, resume boa parte das controvérsias ciceronianas, ao mesmo tempo em que explicita não apenas a posição dos ciceronianos, que reservavam para o latim a posição de língua de aparato, como mostra a que ponto essa polêmica não havia talvez se dado conta de que o latim já se transformava em língua morta:

Ad garriendum de quibuslibet nugis sufficit mibi sermo Gallicus aut Batanicus; profanis ac uulgaribus fabulis non contamino sacram linguam. ${ }^{15}$ (Cic. 44,345 ).

Segundo o testemunho de Boyssonné (in Chomarat, 1981, p. 820, n. 463), os grandes ciceronianos italianos "não apenas não falavam latim em suas conversações familiares de cada dia, como ainda se abstinham religiosamente de o fazer". Ruccellai, por exemplo, que escrevia em excelente latim, recusou-se terminantemente a conversar com Erasmo nesse idioma. Conta-se o mesmo de Bembo. Na caricatura satírica de Erasmo, Nosópono reconhece que terá de se penitenciar pelas "torpezas" que estava cometendo ao manter uma conversação em latim, a qual punha a perder tanto esforço e trabalho (quantum flagitiorum admittam, quantum detrimenti capiam ad id quod molior). "Um mês de leitura dificilmente será suficiente para reparar o dano" (ad sarciendum uix menstrua suffecerit lectio)...

\section{ZêUXIS}

Em outros textos, Erasmo havia estabelecido a diferença entre reddere e exprimere de um lado e, de outro, imitari. Por exemplo, uma criança se parece com seus pais, mas imita os mais velhos (Chomarat, 1981, p. 819). A semelhança é natural; a imitação, voluntária e consciente, pressupõe um julgamento sobre o modelo. Imitar é, assim, escolher. Optar por um modelo dentre muitos e, deste, colher aquilo que é o mais adequado para aquelas circunstâncias.

É do próprio Cícero que Erasmo, sempre sob a persona de Buléforo, extrai sua defesa da imitação eclética, usando, para isso, o exemplo de Zêuxis de Heracleia. O episódio está no De inuentione (II, 1): Zêuxis, ao ser contratado pelos habitantes de Crotona para decorar o templo de Juno, propôs-se a retratar Helena de Troia, e, para isso, solicitou dos cidadãos crotonenses que lhe fossem enviadas as mais belas moças da cidade. Dentre estas, ele elegeu cinco, e, baseando-se nesses modelos vivos diferentes, pintou de cada

${ }^{15}$ Para tagarelar sobre bagatelas quaisquer, basta-me a língua francesa ou a holandesa; não contamino a língua sagrada com conversinhas profanas e vulgares. 
uma a parte mais excelente de seu corpo, a fim de alcançar a perfeição de Helena. Nessa comparação, Buléforo argumenta que é impossível que todas as qualidades retóricas sejam encontradas em um só orador da forma mais aprimorada. A natureza jamais concedeu tanto a um só, e ainda mais com respeito à faculdade oratória, que se constitui da capacidade de discorrer sobre todas as disciplinas. Nem o próprio Cícero teria jamais desejado ser o único modelo, uma vez que havia lançado mão do episódio de Zêuxis em Crotona para ilustrar sua própria teoria da imitação, a qual deve ser ainda mais composta na oratória que na pintura, pois o orador tem a oportunidade de escolher a partir de um estoque de modelos muito mais copioso (ex maiore copia) que aquele do pintor (De inuentione, II, 5). Esses que, como Nosópono, preferem escrever "três epístolas em estilo ciceroniano do que cem volumes em um estilo tão elegante quanto queiras, mas discrepante com o de Cícero" (tres epistulas scribere phrasi Ciceroniana quam centum uolumina stilo quamlibet expolito, modo a Ciceroniano discrepante), pareceriam, segundo Buléforo, "insensatos" (anoi) ao próprio Cícero.

A despeito disso, no entanto, a resposta de Nosópono é que "se Zêuxis houvesse encontrado uma donzela de beleza tão grande quanto aquela que há na eloquência de Marco Túlio, talvez tivesse se contentado com o modelo de só um corpo" (si tali forma uirginem Zeuxis esset nactus, qualis est in eloquentia M-Tullius, fortassis unius corporis exemplo fuisset contentus)...

Mas, prossegue Buléforo, para cada necessidade há um modelo diferente a ser imitado, e Cícero jamais foi considerado o melhor em tudo. Quanto ao uso do humor, por exemplo, melhor copiar algum dos « ditos espirituosos de Otávio" (Octauii dictis). Da mesma forma, se a intenção é usar sententiae no discurso, o bom uso destas deve ser imitado de Sêneca mais do que de Cícero, assim como a concisão deve ser imitada de Salústio ou Bruto, não de Cícero. A seguir, com argumentos extraídos de Bruto, Ático, Catão, Galo, Lárcio, Licínio, Céstio, Calvo, Asínio, Célio, Sêneca e muitos outros, os quais "não apenas não disseram nada de magnífico acerca do talento de Cícero, como até condenaram seu estilo oratório" (qui cum de Ciceronis ingenio non satis magnifice senserunt, tum orationis genus damnarunt), Buléforo lembra que alguns consideraram Cícero "árido, estéril, seco, exangue, frouxo e solto, mole e pouco viril" (aridum, ieiunum, exsucum, exsanguem, elumbem ac dissolutum, mollem ac parum uirum), ao passo que outros o tachavam de «inchado, asiático e redundante de coisas supérfluas" (tumidum, Asiaticum ac superfluis redundantem).

O ciceroniano que não tem outro objetivo senão brilhar pela ostentação de sua imitação sequer pode ser considerado orador, sendo antes um histrião (bistrionem). Dessa forma, aquels que se creem "novos Cíceros" (alteros Cicerones) porque iniciam seu discurso por quamquam ou etsi, ou animaduerti ou cum ou si, e não concluem o período antes de nove linhas, ou usam expressões como etiam atque etiam, estes nem sequer são ciceronianos, mas ridiculos simios. 
E assim por diante, a tal ponto que Nosópono acusa o amigo de "ter premeditado o vitupério de Cícero” (meditatus Ciceronis uituperationem)...

\section{Imitar Cícero em tudo}

Mas Buléforo ainda não esgotou seus argumentos, e continua: imitar Cícero em tudo e em todas as situações é imitá-lo mal, o que expõe ao ridículo imitado e imitador. Pois a este poderia sobrevir o ridículo, de forma não menos infeliz do que a Íxion, o qual abraçou "uma vã imagem de nuvem" (nubis inane simulacrum) em lugar de sua bem-amada Juno, ou a Páris, que fez a guerra durante dez anos pela Helena que havia raptado, enquanto abraçava "uma falsa imagem de Helena" (mendax Helenae simulacrum). Com tantos esforços e penosos sacrifícios, tudo o que a imitação ciceroniana consegue obter é, afinal, apenas "uma sombra vazia e falaz de Cícero" (inanem ac fallacem Ciceronis umbram)...

Ao mesmo tempo, ademais, imitar Cícero em tudo significaria imitar também seus uitia, cuja existência Buléforo vai tentando fazer Nosópono admitir. Cícero não apenas os tinha como também cometeu deslizes e até mesmo equívocos, tais como solecismos, lapsos de memória, "menção desmedida dos próprios louvores" (immoderata mentione propriarum laudum), destempero tanto no autoelogio quanto na invectiva contra os demais, uso de molossos que resultam em construções pesadas, aliterações. Quintiliano (1.7.20) conta ainda que escrevia dois ss sempre que o $s$ antecedia uma vogal longa, como em caussa, uisse, remissi, enquanto que Aulo Gélio (VI, 15) afirma que Cícero "tropeçou" ao atribuir alguns versos da Ilíada a Ájax, quando são de Heitor...

Agora, se for para reviver Cícero em tudo, também seus defeitos, tais como narrados por Plutarco ou Quintiliano, devem ser imitados, como "sua famosa vaidade" (illud subinane), seu tique de "acariciar o queixo com a mão esquerda" (mentum laeua demulceri) e até "seu pescoço comprido e fino" (et collum oblongum atque exilius), sua característica de "falar sempre em voz muito alta" (perpetuam uocis contentionem), "sua indecorosa e pouco viril agitação no começo do discurso" (indecoram parumque uirilem in initio dicendi trepidationem), "sua falta de medida nos gracejos" (iocorum intemperantiam). Além disso, tinha ainda um tipo de expressão tão fluido que às vezes pode parecer frouxo e solto (remissus ac solutus) ; uma abundância de palavras tão exuberante que pode parecer redundante (tam exuberans uerborum copia, ut redundans); tão grande observância da técnica (tam artis obseruans) que parece mais próximo de um declamador que de um orador, procurando, por vezes, a glória da maestria na arte (artificii) à custa da credibilidade (fidei factura); é tão pródigo em atacar (tam liber in insectando) que poderia passar por maledicente (maledicus); tão efusivo em gracejos (tam effusus in iocos) que, quando era cônsul, conseguiu a proeza de levar Catão ao riso; tão lisonjeiro (tam blandus), às vezes, que pode parecer abjeto (abiectus); tão alinhado (tam compositus) que foi chamado de mole (mollis) e de pouco viril (parum uir) por 
naturezas mais severas...

Diante desses argumentos, Nosópono se limita a responder que "é próprio dos amantes cobrir de beijos (exosculari) até as verrugas (etiam naeuos) daquelas a quem amam”...

Aqui, Buléforo não deixa de lembrar também que muitas frases reverenciadas como perfeitas não o seriam, se não tivessem sido escritas por Cícero. Ecoando a correspondência de Pico della Mirandola a Pietro Bembo, em que aquele conta o episódio em que um homem confundiu os críticos ao forjar uma correspondência de Cícero, Erasmo satiriza a reverência com que é tratado qualquer fragmento atribuído ao Arpinate.

Nec enim semel lusum hunc uidimus. Fragmentum e Cicerone decerptum addito Germani cuiuspiam titulo quam deridebant, quoties barbarum inclamabant, qui sibi ualde Ciceroniani uidebantur! Rursus aliquid pridie confictum proferabatur in medium, addebatur Ciceronis nomen et fingebatur exemplar repertum in bibliotheca peruetusta: quam exosculabantur, quam adorabant diuinam illam et inimitabilem Ciceronis phrasim. ${ }^{16}$ (Cic. 74, 511-512).

Mas, prossegue, ainda que se admita que em Cícero todas aquelas características não são vícios, mas até mesmo virtudes, ainda assim "ocorrem nele de tal forma que, por causa dessa vizinhança (ob uiciniam), não deixam de ter aparência de vícios (specie uitiorum), sob um juiz injusto" (sub iniquo iudice). E é perigoso imitá-las, se o imitador não sabe reproduzir também as qualidades com que são compensados.

E ainda que fosse possível existir alguém capaz de imitar Cícero em tudo, ainda assim faltaria a este imitador o principal. Pois, ao imitar seu modelo, o discípulo teria, como Zêuxis ao pintar, reproduzido de seu modelo "os traços, a cor, a idade (lineamenta colorem aetatem) e mesmo algo de sentimento (affectus nonnibil), isto é, algo de dor (dolentis), de alegria (gaudentis), de ira (irati), de medo (metuentis), de atenção (attenti) ou de sonolência (dormitantis)", demonstrando assim a mais alta técnica artística e esgotando tudo aquilo de que a arte é capaz. Mas isso não seria Túlio, como mesmo o melhor retrato não é a pessoa viva.

Agnoscis formam eius, quae depicta est, uides aetatem et affectus, fortassis et ualetudinem; adde quod a quibusdam effectum legimus: agnoscit indolem et mores et

${ }_{16}$ Pois vimos esta brincadeira mais de uma vez: extraído um fragmento de Cícero, acrescentava-se-lhe o nome de algum alemão. Como zombavam, a cada vez que aqueles que se arrogavam muito ciceronianos o chamavam de bárbaro! Ou, ao contrário, divulgava-se em público alguma coisa escrita na véspera, acrescentando-se-lhe o nome de Cícero, e se inventava que era um exemplar descoberto em uma biblioteca muito antiga. Como o cobriam de beijos, como adoravam aquela divina e inimitável frase de Cícero! 
uitae spatium physiognomon. Sed imane quantum illic abest hominis! Quod ex summa cute conici potest, expressum est. Ceterum, cum bomo constet ex anima et corpore, quantulum illic est unius partis eiusque deterioris? Vbi cerebrum, ubi caro, ubi uenae, ubi nerui et ossa, ubi intestina, ubi sanguis spiritus et phlegma, ubi uita, ubi motus, ubi sensus, ubi uox et sermo, denique ubi, quae sunt hominis propria, mens ingenium memoria consilium? Quemadmodum, quae sunt hominis praecipua, pictori sunt inimitabilia, ita summas oratoris uirtutes nulla assequitur affectatio, sed a nobis ipsis sumamus oportet. Verum a pictore nibil aliud exigitur, si praestitit quod unum ars profitetur; a nobis, si totum Ciceronem exprimere uolumus, multo aliud requiritur. Si nostrum simulacrum, quo $M$-Tullium effingimus, careat uita actu affectu neruis et ossibus, quid erit imitatione nostra frigidius? Sed multo magis erit ridiculum, si tuberibus neruis cicatricibus aliaue membri deformitate demum efficiamus, ut lector agnoscat nos legisse Ciceronem. ${ }^{17}$ (Cic. 108, 680-688).

Há toda uma teoria das artes imitativas em Erasmo, mas baste-nos, aqui, compreender que, para o holandês, imitar não é copiar a forma exterior, sempre mutável, mas sim captar o espírito do imitado. Daí a anedota contada por $\mathrm{Hi}^{-}$ pólogo acerca de certo Múrio, que, tendo encomendado seu retrato a um pintor, foi sendo sucessivamente pintado conforme as roupas que usava, a barba daquele dia, a luz do ambiente, as transformações que seu rosto sofria em decorrência de resfriados etc. Esse retrato, por mais realista que fosse, conseguiria apenas representar aspectos exteriores, acidentais. Por mais que alguém consiga representar Cícero quanto a suas expressões, trejeitos, características e até humores, "onde está aquele famoso coração de Cícero (ubi pectus illud Ciceronis)?”.

Sed finge nos feliciter expressisse in Cicerone, quicquid hominis exprimere potest absolutus pictor; ubi pectus illud Ciceronis, ubi rerum tam copiosa, tam felix inuentio, ubi dispositionis ratio, ubi propositionum excogitatio, ubi consilium in tractandis argumentis,

${ }^{17}$ Reconheces a figura da pessoa que foi pintada, vês sua idade e seus sentimentos, e talvez também seu estado de saúde; acrescenta o que se conta que alguns conseguiram: o fisiognomista reconhece sua índole e seus costumes e seu espaço vital. Mas ainda é enorme o quanto falta ali da pessoa! $\mathrm{O}$ pintor reproduziu o que se pode conjecturar a partir da superfície da pele. Mas, uma vez que o homem se constitui de alma e de corpo, quão pouco há ali de uma parte só, a pior! Onde está o cérebro, onde a carne, onde as veias, onde os nervos e os ossos, onde os intestinos, onde o sangue, onde a respiração e a fleuma, onde a vida, onde o movimento, onde os sentidos, onde a voz e a linguagem, onde, enfim, as coisas que são próprias do homem, a mente, a inteligência, a memória, a capacidade de decisão? Assim como um pintor não consegue imitar as qualidades principais de um homem, assim também nenhuma tentativa de reproduzir um efeito alcança as principais virtudes de um orador. É preciso que as tiremos de nós mesmos. De fato, não se exige nada mais do pintor, se ele apresenta o que é próprio da arte que professa; mas de nós, se quisermos imitar Cícero inteiro, requer-se algo muito diferente. Se a imagem com a qual retratamos Marco Túlio carecer de vida, de ação, de sentimentos, de nervos e de ossos, que haverá de mais frio que nossa imitação? Mas muito mais ridículo será se, com protuberâncias, nervuras, cicatrizes e outras deformidades físicas, conseguirmos finalmente que o leitor reconheça que nós lemos Cícero. 
ubi uis in mouendis affectibus, ubi iucunditas in delectando, ubi tam felix ac prompta memoria, ubi tantarum rerum cognitio, denique ubi mens illa spirans etiam num in scriptis, ubi genius ille peculiarem et arcanam afferens energiam? Haec si absint, quam erit frigidum imitationis nostrae simulacrum?18 (Cic. 112, 698 a 114, 699).

É preciso ainda distinguir a imitação servil da aemulatio, a qual pressupõe a possibilidade de superar um modelo tomado não como ponto de chegada, mas de partida. Aquele que tiver a pretensão de vencer a Cícero, e só a Cícero, com as armas dele, está condenado à derrota, precisamente por competir com ele naquilo em que ele é o ponto mais alto.

Itaque, si totum et unum Ciceronem tibi proposueris, non in boc tantum, ut illum exprimas, uerum etiam, ut uincas, non praeter currendus erit, sed reliquendus magis. Alioqui, si illius copiae uelis adere, fies redundans, si libertati, fies petulans, si iocis, fies scurrilis, si compositioni, fies pro oratore cantor. Itaque fit, ut, si Tullium aequare studeas, pericliteris ne hoc ipso peius dicas, quod diuinas hominis uirtutes, quibus ea pensauit, quae uel uitia sunt uel uitio proxima, non possis assequi, cetera nimirum assecutus, sin coneris et anteuertere, etiamsi in illis quae nullo studio possis assequi paria cum illo facias, tamen uitiosum erit quicquid Ciceroni fuerit adiectum. ${ }^{19}$ (Cic. 124, 765-767).

Diante disso, e antes de mais nada, deve-se imitar Cícero apenas nas ocasiões em que seja ele o melhor modelo. Escrever ciceroniano more sobre qualquer tema, em qualquer situação, seria como "se alguém pintasse um asno com aparência de boi, ou um falcão com forma de cuco, ainda que no restante aplicasse a esse quadro um cuidado e uma arte supremos" (si quis asinum pingeret specie bubali aut accipitrem figura cuculi, etiamsi ad eam

${ }^{18}$ Onde sua invenção de temas tão copiosa, tão fértil, onde seu método de disposição, onde o desenvolvimento de suas proposições, onde sua ponderação ao tratar os argumentos, onde seu poder de mover as paixões, onde seu encanto para deleitar, onde sua memória tão fértil e rápida, onde seu conhecimento de tantos temas, onde, enfim, aquela famosa inteligência que se respira até hoje em seus escritos, onde aquela famosa genialidade que produz uma peculiar e secreta energia? Se faltam estas coisas, quão fria será a imagem de nossa imitação!

${ }^{19}$ Assim, se te propuseres como modelo só e inteiramente Cícero, e tua intenção for não somente reproduzi-lo, mas também vencê-lo, ele não será ultrapassado, mas antes terás de abandonar o corrida. Por outro lado, se quiseres acrescentar algo a sua abundância, tornar-teás redundante; se algo a sua falta de cerimônia, tornar-te-ás petulante; se algo a seus gracejos, tornar-te-ás um bufão; se algo a sua composição, tornar-te-ás um cantor, em vez de orador. Assim, se te empenhares em igualar a Túlio, correrás o risco de falar pior do que ele, pela simples razão de que não poderás alcançar as divinas virtudes com que ele compensou aquelas coisas que ou são vícios ou estão próximas do vício, mesmo que certamente tenhas alcançado outras; ao passo que, se tentares ultrapassá-lo, ainda que faças escritos parelhos com os seus, inclusive naquelas características que não poderás reproduzir por mais que te empenhes, ainda assim será vicioso tudo aquilo que houver sido acrescentado a Cícero. 
tabulam summam alioqui curam et artem adbiberet). Da mesma forma, não será ciceroniano alguém que "discorra sobre os paradoxos dos estoicos e sobre as argúcias de Crisipo no teatro, ou que no Areópago se entregue a chacotas em julgamentos de crimes capitais, ou que fale de arte culinária com as palavras e as figuras dos trágicos" (si quis in theatro disserat de Stoicorum paradoxis deque Chrysippeis argutiis aut apud Areopagitas in capitis discrimine lasciniat facetiis aut de re culinaria uerbis ac figuris tragicorum loquatur). O estilo é a roupa que cada tema deve usar; assim como há um traje para cada idade, ocasião, sexo etc, assim o estilo é um para cada circunstância. E, assim como a moda, a elocutio muda segundo os tempos. O próprio Apeles pintaria mal hoje, se pintasse os homens de hoje tal como pintou os gregos antigos (tales pingeret Germanos, quales olim pinxit Graecos).

Tampouco se poderia chamar honesto ao pintor que, no quadro, "tornasse bonito um homem feio" (deformem hominem in tabula formosum redderet), ainda que, no mais, demonstrasse uma "arte excelente" (summam artem), uma vez que o quadro pode não ser desprovido de arte, mas é "mentiroso" (mendax). Ademais, um artista que priorize o tecnicismo artístico sobre a verdade não é um homem bom. Sua arte é sofística.

Nam uestri rhetores permittunt oratori mentiri nonnunquam, res bumiles uerbis attolere, magnificas deicere, quod sane praestigii genus est, obrepere insidiis in animum auditoris, postremo mouendis affectibus, quod ueneficii genus est, uim adferre mentibus. ${ }^{20}$ (Cic. 132, 817).

Por esses motivos, lembra Erasmo na pessoa de Buléforo, aquele que mais se esforça para ser ciceroniano é, ele, o mais anticiceroniano possível.

É preciso ainda, para falar de forma apropriada, levar em conta as circunstâncias. Pois falar como o antigo romano no século XVI é falar mal. Isso resulta do fato de que tudo mudou: a religião, o império, as magistraturas, a república, as leis, os costumes, os estudos e até mesmo a própria aparência dos homens (ipsa hominum facies). Em todos os assuntos da vida cotidiana, como a eleição de um magistrado, o casamento etc, em tudo é preciso expressar-se de forma diferente do que aquela que Cícero usava para falar em sua época. E, nessas novas situações, perante esse público diferente e tendo esses temas, de que serviria ao orador contemporâneo a eloquência de Cícero? Este não poderia senão falar como se costurasse "os panos arrancados de Cícero" (ueluti panos Ciceroni detractos assuat).

${ }^{20}$ Pois vossos rétores por vezes permitem ao orador mentir, elevar com palavras as coisas humildes, rebaixar as grandes e, o que certamente é uma espécie de embuste, introduzir-se no ânimo dos ouvintes com insídias; enfim, violentar as mentes para comover as paixões, o que é um tipo de feitiçaria. 
Reddat is nobis prius Romam illam quae fuit olim, reddat senatum et curiam, patres conscriptos, equestrem ordinem, populum in tribos et centurias digestum, reddat augurum et haruspicum collegia, pontifices maximos, flamines et uestales, aediles, praetores, tribunos plebis, consules, dictatores, Caesares, comitia, leges, senatus consulta, plebiscita, statuas, triumphos, ouationes, supplicationes, fana, delubra, puluinaria, sacrorum ritus, deos deasque, Capitolium et ignem sacrum, reddat prouincias, colonias, municipia et socios urbis rerum dominae. Porro, cum unde quaque tota rerum humanarum scena inuersa sit, quis hodie potest apte dicere nisi multum Ciceroni dissimilis? Adeo mibi uidetur hoc quod agebamus in diuersum exisse. Tu negas quenquam bene dicere, nisi Ciceronem exprimat, at res ipsa clamitat neminem posse bene dicere, nisi prudens recedat ab exemplo Ciceronis. Quocunque me uerto, mutata omnia, in alio sto proscenio, aliud conspicio theatrum, immo mundum alium. ${ }^{21}$ (Cic. 134, 835 a 136, 838).

O mais semelhante a Cícero, por conseguinte, é aquele que mais parecer diferente dele, isto é, aquele que fala da forma melhor e mais conveniente, ainda que fale de modo diferente, uma vez que é evidente que as coisas mudaram por completo. E, dentre todas as transformações por que o mundo passou desde os tempos da República romana, a mais importante segundo Erasmo, aquela que mais esvazia de sentido os discursos dos ciceronianos, tornando-os inadequados, é o advento do Cristianismo.

\section{Paganitas}

Erasmo se utiliza de um tema que lhe era especialmente caro, a epistolografia, para começar a transição para um tema mais amplo dessa discussão, que é o fato de que o veto ao emprego de palavras que não fossem encontradas em Cícero tinha como resultado imediato simplesmente vetar também todo o vocabulário cristão.

Ele começa pela afirmação irônica de que o orador pode perder seu título de ciceroniano se escrever uma carta em que anote o ano no cabeçalho, ou colocar

${ }^{21}$ Que primeiro nos devolva aquela Roma que havia outrora, que nos devolva o Senado e a cúria, os pais conscriptos, a ordem equestre, o povo dividido em tribos e centúrias; que nos devolva os colégios de áugures e arúspices, os pontífices máximos, os flâmines e as vestais, os edis, os pretores, os tribunos da plebe, os cônsules, os ditadores, os césares, os comícios, as leis, os decretos do Senado, os plebiscitos, as estátuas, os triunfos, as ovações, as súplicas, os templos, os ídolos, os santuários, os ritos sagrados, os deuses e as deusas, o Capitólio e o fogo sagrado; que nos devolva as províncias, as colônias, os municípios e os aliados da cidade senhora de todas as coisas. Além disso, uma vez que todo o cenário das coisas humanas se inverteu por toda parte, quem pode hoje em dia falar convenientemente, a não ser alguém diferente de Cícero? A tal ponto que me parece que aquilo de que tratávamos tenha saído em sentido contrário! Tu negas que alguém fale bem, a menos que imite Cícero; no entanto, a própria realidade está gritando que ninguém pode falar bem, a menos que se afaste prudentemente do exemplo de Cícero. Para onde quer que me volte, tudo mudado, vejo-me em outro proscênio, contemplo outro teatro, e mais, outro mundo. 
o nome daquele a quem se escreve antes do seu próprio, uma vez que são coisas que Marco Túlio não fazia. Se não podem perdoar a Plínio, o Jovem o fato de que chame suus o amigo a quem escreve, uma vez que em Cícero não se encontra nenhuma ocorrência desta prática, proíbem, igualmente, a saudação S.P.D., pois "negavam que aquela pudesse ser encontrada em Cícero" (quod negarent hoc apud Ciceronem inueniri).

Mas muito mais longe de ser ciceroniano estará aquele que tiver começado uma carta com a expressão paulina gratia, pax, et misericordia a Deo patre et domino Iesu Christo...

Quos risus, quos cachinnos hic tollent Ciceroniani? Quid autem admissum est piaculi? An non uerba Latina sunt, munda, sonantia atque etiam splendida? Iam si sensum introspicias, quanto plus est hic quam in "salutem dicit" et "bene uale"? Quid uulgarius quam dicere salutem? Praestat hoc officium herus seruo, inimicus inimico. Quis autem crederet esse Latinum "dicit illi salutem" et "iubet illum saluere", nisi nobis sermonem bunc ueterum consuetudo commendaret? Hoc in aditu. Iam in digressu "uale" dicimus et his, quibus male precamur. Quanto melior emphasis in formulis Christianorum, si modo uere et ex animo simus Christiani. "Gratia" declarat gratuitam condonationem admissorum, "pax" quietem et gaudium conscientiae, quod Deum pro irato habemus propitium, "misericordia" dotes uarias et corporis et animi, quibus suos locupletat arcani Spiritus benignitas, quoque magis speremus nobis haec fore perpetua, additur " a Deo patre et Domino nostro Iesu Christo". Cum "patrem" audis, ponis seruilem trepidationem ascitus in affectum filii, cum "Dominum" audis, confirmaris aduersus uires satanae. Non deseret ille, quod tam care redemit, et unus potentior est uniuersis satanae cohortibus. Quid suauius his uerbis ei, qui iam haec apud se sentit, quid utilius hac admonitione ei, qui nondum in bunc affectum transiit. Verbis itaque non uincimur, immo uincimus potius, sententia longe superamus. Restat illud decorum et aptum, quod ubique cum primis spectadum est. At haec quanto magis conueniunt homini Christiano quam illa "salutem dicit" et "cura ut ualeas"?22 (Cic. 98, 630 a 100, 646).

${ }^{22}$ Que risadas, que gargalhadas soltarão então os ciceronianos! Mas que sacrilégio se cometeu? Acaso não são palavras latinas, elegantes, sonoras e até esplêndidas? Já, se penetras no sentido, quão maior é o que há aqui do que em salut dicit, "envia saudações" e bene vale, "passa bem”! Que há de mais vulgar do que dizer salutem, "saudações”? Trata-se de um dever que o amo tem para com o escravo, o inimigo para com o inimigo. [...] Já para terminar, dizemos vale, "passar bem", até para aqueles a quem queremos mal. Como é melhor aquilo a que se dá ênfase nas fórmulas dos cristãos, se é que somos verdadeiramente cristãos de coração! O termo "graça" indica o perdão gratuito dos pecados cometidos; "paz", a tranquilidade e a alegria de consciência, porque temos um Deus propício, em vez de um irado; "misericórdia", os vários dotes do corpo e do espírito com os quais a benignidade do Espírito arcano enriquece os seus; e, para que também esperemos que estas coisas sejam eternas para nós, acrescenta-se "de Deus Pai e de Nosso Senhor Jesus Cristo". Quando ouves "Pai”, depões o temor servil, pois foste admitido no afeto de um filho; quando ouves "Senhor", te pões firme contra as forças de 
Nula é a pertinência da elocução ciceroniana, se o orador cristão tem de se dirigir a uma multidão heterogênea (promiscuam multitudinem), formada também por mulheres (et uirgines et uxores et uiduae), para tratar de temas como "o mérito do jejum, a penitência, o fruto da oração, a utilidade das esmolas, a santidade do matrimônio, o desprezo das coisas efêmeras, o estudo das divinas escrituras" (de laude ieiunii, de paenitentia, de fructu orandi, de utilitate eleemosynarum, de sanctitate matrimonii, de contempto rerum fluxarum, de studio diuinarum literarum).

Para ilustrar a incongruência de um discurso tuliano quando nem o tema nem as circunstâncias nem o público o exigiam, e, ao mesmo tempo, acusar a paganitas dos ciceronianos, Erasmo passa a narrar então, pela boca de Buléforo, "não rumores que me chegaram, mas aquilo que ouvi com estes ouvidos e vi com estes olhos" (non rumore perlata, sed quod his auribus audiui, his oculis conspexi). Se aceitarmos as evidências de que se trata de um dado biográfico de Erasmo, tudo aponta para um evento ocorrido na Sexta-Feira Santa de uma data tão recuada quanto 1509 , quando, em visita a Roma, ele teria assistido pessoalmente à actio de um famoso orator que, diante do Papa Júlio II e dentro da catedral da sede da Igreja romana, proferiu um discurso ciceroniano, com palavras pagãs. Tudo indica que se tratava de Tommaso Inghirami, conhecido como "Fedra" e chamado o Cícero de sua época. Sem mencionar o nome do orador, "para que não pareça a alguém que eu quereria arruinar a fama de um homem probo e erudito" (ne cui uidear hominis probi et eruditi famam arrodere uoluisse), cujo mal era ser "candidato à facúndia ciceroniana" (Ciceronianae facundiae candidatus), Erasmo conta o episódio, em que, "a certa pessoa" (cuipiam) fora encarregada a missão de falar sobre a morte de Cristo na sexta-feira da Paixão, perante o Sumo Pontífice, em detalhes:

Aliquot ante diebus ad eam orationem audiendam sum inuitatus ab eruditis. Caue, inquiebant, ne desis; nunc demum audies, quid lingua Romana sonet in ore Romano. Adfui percupide, astiti suggesto proximus, ne quid effugeret. Aderat ipse Iulius secundus, quod solet, ualetudinis opinor causa, admodum raro, aderat frequens cardinalium episcoporumque consessus ac praeter ignobilem turbam docti plerique, qui tum Romae agebant. ${ }^{23}$ (Cic. 138, 848-851).

Satanás. O Senhor não abandonará aquilo que resgatou a preço tão caro, e ele sozinho é mais poderoso que todas as legiões de Satanás. Há algo mais suave do que estas palavras para quem já sente isso em seu interior, mais útil do que este aviso para quem ainda não ingressou nesse amor? Assim, não somos vencidos por causa de palavras, mas antes vencemos nós; naquilo que significam, somos muito superiores! Resta o que é decoroso e conveniente, a que devemos visar primeiro em toda parte. E como convêm mais ao cristão estas palavras do que "envia saudações" e "cuida-te e passa bem"!

${ }^{23}$ Alguns dias antes, havia sido convidado por eruditos a ouvir tal discurso. "Procura não faltar", diziam-me, "então ouvirás afinal como a língua romana soa em boca romana”. Fui 
A estratégia retórica do orador foi evocar os Décios e Quinto Cúrcio, assim como Cécrope, Meneceu, Ifigênia e tantos outros, "para os quais a salvação e a dignidade da pátria haviam sido mais caras do que a própria vida" (quibus patriae salus ac dignitas ipsa uita fuisset carior), ao mesmo tempo em que lamentava o fato de que honrarias e privilégios haviam sido concedidos "aos homens valentes que haviam corrido perigos para vir em socorro da República" (fortibus uiris, qui suis periculis reipublicae subuenissent), ao passo que Jesus recebeu "uma cruz em lugar de um prêmio" (praemii loco tulisse crucem). Assim, equiparava Cristo a Sócrates e Focião, a Epaminondas, Cipião e Aristides, mas sem jamais mencionar a Deus... É fato que "um romano dizia estas coisas em Roma, com boca romana e sotaque romano" (baec quidem Romae Romanus ore Romano sonoque Romano). Mas que têm a ver essas coisas com o cristianismo? Assim, além de não ser pertinente à res, o referido discurso tampouco é capaz de mouere. Nada poderia ser "mais sagrado, mais verdadeiro, mais admirável, mais sublime, mais apropriado para mover as paixões" (quid sacratius, quid uerius, quid mirabilius, quid sublimius, quid commouendis affectibus accomodatius) que o argumento que já havia recebido para tratar, ou seja, a morte de Cristo. Com tal tema, diz Erasmo, qualquer um, "ainda que dotado de uma eloquência vulgar" (uulgari quapiam eloquentia praeditus), "teria arrancado lágrimas até de homens de pedra" (saxeis etiam hominibus excitet lacrimas). Mas, em vez disso, o orador preferiu tornar a morte de Cristo "gloriosa e triunfal" (gloriosam ac triumphalem), "sem dúvida para dar-nos uma demonstração da famosa indignação ciceroniana" (nimirum ut nobis exbiberet exemplum Ciceronianae dinoseos), e para aproximar a morte de Jesus das mortes dos heróis romanos. E, com isso, sua fala, embora fosse a mais vívida reprodução de um discurso ciceroniano, nem persuadiu, nem ensinou nem comoveu, ou seja, não atingiu nem um único objetivo de um discurso. E, sendo assim, pergunta: "o que se poderia dizer de mais frio ou mais inepto (frigidius aut ineptius)?”.

Tam Romane dixit Romanus ille, ut nibil audirem de morte Christi. Et tamen ille Ciceronianae dictionis ambitiosissimus candidatus Ciceronianis uidebatur mirifice dixisse, cura de re paene nibil diceret, quam nec intelligere nec amare uidebatur, neque quicquam apposite dicebat nec ullos mouerat affectus. Tantum hoc laudis ferebat, quod Romane pronuntiasset et aliquid Ciceronis rettulisset. Probari poterat hoc uelut indolis ingeniique specimen, si a puero apud pueros in schola fuisset habita talis oratio. Verum ad talem diem, ad tales auditores, ad tale argumentum quid faciebat, obsecro? ${ }^{24}$ (Cic. 144, 876-880).

com grande ansiedade e fiquei próximo do púlpito, para que nada se me escapasse. O próprio Júlio II estava presente, coisa que acontece muito raramente, creio que por motivo de saúde; estava presente uma grande assembleia de cardeais e de bispos, e, além de uma multidão desconhecida, muitos doutores que então viviam em Roma.

${ }^{24}$ Aquele romano falou de forma tão romana que eu não ouvi nada sobre a morte de Cristo. $\mathrm{E}$, no entanto, parecia aos ciceronianos que aquele ambiciosíssimo candidato à eloquência 
Ao "grande orador", no entanto, escapou que Paulo teria sido um modelo muito mais adequado que Cícero, naquelas circunstâncias. Mas isso ele não poderia ter feito... Cícero, sendo pagão, retirava dos pagãos os ornamentos dos seus discursos; mas um cristão não pode proceder da mesma forma com os textos os cristãos, porque os ciceronianos julgam que uma citação de Platão acrescenta "peso e majestade ao discurso" (pondus ac maiestatem); mas uma sentença de Cristo tomada dos evangelhos, dizem os ciceronianos, parece que faz o discurso perder muito em graciosidade (plurimum gratiae decessisse uidetur).

Hoc accepimus, hoc penitus insedit animis nostris uoces illas esse politas ac splendidas, has inamoenas et barbaras. ${ }^{25}$ (Cic. 170, 988).

E a razão disso é uma só: a paganitas. Monge reticente, Erasmo era, por outro lado, um cristão convicto, que fundamentava sua crítica aos ciceronianos também na divinização de Cícero que promoviam. Para ele, aqueles humanistas italianos que, em nome da admiração pelas letras antigas, rejeitavam o rude e rústico estilo baixo cristão eram membros de uma secta.

Nusquam apud Ciceronem legimus Iesu Christi, uerbi Dei, spiritus sancti aut trinitatis uocabulum nec "euangelium" nec "euangelistam" nec "Mosen" nec "prophetam" nec "pentateuchum" nec "psalmos" nec "episcopum" nec "archiepiscopum" nec "diaconum" nec "bypodiaconum" nec "acoluthum" nec "exorcistam" nec "ecclesiam" nec "fidem", "spem" et "caritatem" nec "trium personarum eandem essentiam" nec "baeresim" nec "symbolum" nec septem ecclesiae sacramenta nec "baptismum" aut "baptistam" nec "confirmationem" nec "eucharistiam" nec "sacrum unctionem" nec "poenitentiam" nec "sacramentalem confessionem" nec "contritionem" nec "absolutionem" nec "excommunicationem" nec "ecclesiasticam sepulturam" nec "missam" nec alia innumera quibus constat omnis uita Christianorum. ${ }^{26}$ (Cic. 150, 907).

ciceroniana havia falado maravilhosamente, quando não tinha dito nada sobre o assunto em questão, do qual parecia nem entender nem gostar; e tampouco dizia nada adequado, nem havia movido as paixões. Tão só apresentava o mérito de haver pronunciado à maneira romana e de haver reproduzido algo de Cícero. Poder-se-ia aprová-lo como exemplo de sua inclinação natural e de seu talento, se tal discurso tivesse sido feito por um menino perante outros meninos na escola. Mas, em um tal dia, perante tal auditório, relativo a tal tema, que estava fazendo, por favor?

${ }^{25}$ Nós aceitamos isto, isto se arraigou profundamente em nossos espíritos: que aquelas palavras são polidas e esplêndidas, enquanto que estas são desagradáveis e bárbaras.

${ }^{26}$ Nunca lemos em Cícero as palavras "Jesus Cristo", "Palavra de Deus", "Espírito Santo" ou "Trindade", nem "Evangelho", nem "evangelista", nem "Moisés", nem "profeta”, nem "Pentateuco", nem "salmos", nem "bispo", nem "arcebispo", nem "diácono”, nem "subdiácono", nem "acólito", nem "exorcista”, nem "Igreja”, nem "fé”, "esperança” e "caridade”, nem "mesma essência das três pessoas", nem "heresia", nem "símbolo", nem "sete sacramentos da Igreja", nem "batismo" ou batista, nem "confirmação", nem "eucaristia”, nem "sagrada unção", 
Ou ainda :

Corpus aqua sacra tinctum est, sed illota mens est; frons cruce signata est, animus crucem exsecratur; Iesum ore profitemur, sed Iouem Optimum Maximum et Romulum gestamos in pectore. ${ }^{27}$ (Cic. 170, 1002).

Pressionado pela Reforma e assombrado pelo recente saque de Roma, em maio de 1527, Erasmo parece se exasperar com o fato de que grande parte do clero pareça se dedicar não a salvar a cristandade, mas a reavivar o paganismo.

\section{Genius}

Assim, não podemos perder de vista que a acusação de paganismo não é apenas retórica. Se é verdade que o pregador cristão que fala ciceroniano more não atinge seu auditório nem cumpre a tarefa que lhe foi atribuída, também é verdade que uma das críticas fundamentais ao ciceronianismo no diálogo erasmiano se funda sobre a noção de que o ethos do orador não é somente uma construção discursiva, mas sim uma forma de apreender o caráter "real", exterior ao discurso, daquele que fala. Se utilizava a sátira com propósitos educativos e moralizantes e criticava de forma tão mordaz as cerimônias eclesiásticas que lhe pareciam sem sentido, uma vez que eram praticadas por quem não as entendia, era porque a Erasmo repugnava a hipocrisia. Em sua réplica a Longueil, Erasmo havia escrito: sic sum, nec possum naturam uincere. Effundo verius quam scribo omnia (in Allen 935, 1.32-34). Apresentando-se como um cristão sincero, não podia senão afirmar e entender que "a boca fala daquilo de que o coração está cheio", e em parte alguma fez a defesa de um discurso descolado da realidade, que não refletisse a vida e as predisposições do orador. Assim, por um lado, o ciceroniano, ao falar e escrever como um pagão, não faz senão demonstrar seu paganismo; e, por outro, ao imitar Túlio de forma servil, não faz senão destruir sua singularidade, uma vez que, assim, apaga os traços de seu próprio genius.

A metáfora do discurso como espelho que reflete a imagem autêntica daquele que fala é recuperada de Isócrates $(\mathrm{XV}, 255)$ e reaparece com frequência: um livro revela seu autor exatamente como um espelho reflete aquele que está diante dele : sermo hominis verax imago est mentis, sic oratione quasi speculo reddita (Eccles. LB

nem "penitência”, nem “confissão sacramental”, nem "contrição”, nem "absolvição", nem "excomunhão", nem "sepultura eclesiástica”, nem "missa”, nem outras inumeráveis palavras das quais consiste toda a vida dos cristãos. São palavras que, seja qual for o assunto sobre o qual tratas de falar, sempre nos vêm ao encontro e se impõem mesmo àquele que não as quer.

${ }^{27}$ Somos cristãos só de nome; nosso corpo foi banhado com água benta, mas nossa mente não está lavada; nossa fronte foi marcada com o sinal da cruz, mas nosso espírito execra a cruz; confessamos a Jesus com a boca, mas é Júpiter Ótimo Máximo e Rômulo que levamos no peito. 
V 772 BC). As virtudes discursivas não podem ser imitadas porque não podem ser aprendidas pelo exemplo ou por meio de preceitos, mas vêm de dentro. Um discurso que vise a expressar Cícero, não seu autor, é necessariamente falso. $\mathrm{O}$ ciceronianismo é, assim, duplamente nocivo: atenta contra o cristianismo tanto quanto atenta contra a personalidade individual de cada orador. O optimum genus dicendi, portanto, é aquele que dá conta da infinita variedade de temas e ocasiões, mas também dos diferentes caracteres dos homens que, ao falar, devem expressar sua natureza.

\section{O DE OPTIMO GENERE DICENDI.}

Quando da publicação do Ciceronianus, Erasmo já havia se tornado uma espécie de porta-voz da uarietas. Isso se deu especialmente com o sucesso de seu manual De Copia, o manual de retórica mais reimpresso do Renascimento, e certamente o mais estudado ${ }^{28}$. A ideia fundamental é que tudo na vida é vário, e, assim, a diversidade mesma dos objetos pede a varietas do dizer. Monotonia por monotonia, Erasmo não deixa nem mesmo de conceder um elogio aos escolásticos, cujo latim havia execrado tantas vezes. Afinal, Tomás de Aquino e Duns Scott, contra os quais havia investido tão pesadamente em outras ocasiões, falam de temas cristãos de forma muito mais adequada que os ciceronianos.

Mas a uarietas não reflete apenas a diversidade dos objetos, mas também aquela dos sujeitos. Por isso, Erasmo passa em seguida a elencar recomendações inspiradas em um autor de sua predileção, Quintiliano. O "primeiro conselho": "que ninguém cujo talento seja totalmente incompatível com o talento de Cícero dedique-se a reproduzir a Cícero" (ne quiuis sese addicat ad exprimendum Ciceronem, cuius genius uehementer abhorreat a genio Ciceronis). Caso contrário, "acabará semelhante a um monstro aquele que, tendo abandonado sua própria forma inata, não alcance tampouco a alheia” (alioqui monstri similis euadet qui, cura a sua natiua forma recesserit, alienam tamen non assequatur).

Qui Musis natus est, nunquam felix erit in bello. Qui bello natus est, nunquam scribet felicia poemata. Qui coniugio natus est, nunquam erit bonus monachus. Qui agriculturae natus est, nunquam buic erit aula prospera et contra. ${ }^{29}$ (Cic. 180, 1047-1050).

Quando Nosópono responde que "não há nada que o trabalho tenaz não

28 Pela estatística de Peter Mack (2011, p. 76), De Copia teve 60 edições nos primeiros dezoito anos após sua primeira aparição, e atingiu a marca impressionante de 165 edições até 1569 , o que dá uma média de três reedições por ano, e chegou a 168 edições em 1580 . Ronsard, Rabelais e Montaigne foram alguns dos autores cujos experimentos estilísticos foram influenciados pelos ensinamentos de Erasmo sobre a copia (Cave, 1979, p. 326).

${ }^{29}$ Quem nasceu para as musas nunca terá êxito na guerra. Quem nasceu para a guerra nunca escreverá bons poemas. Quem nasceu para o casamento nunca será um bom monge. Quem nasceu para a agricultura nunca achará próspero o palácio, e vice-versa. 
possa vencer" (nibil est quod non expugnet "labor improbus"), e que, pelo artifício humano, "a pedra é transformada em água, o chumbo em prata, o bronze em ouro" (arte humana lapidem uerti in aquam, plumbum in argentum, aes in aurum) e que nada impede que "o talento de um homem se transforme com a arte e com a prática" (quid uetat quominus et hominis ingenium arte et usu transformetur), a resposta é que em vão seria atormentado um talento forjado pela natureza para coisas diferentes.

Quid dissimilius quam smaragdus et pyropus et tamen pretio gratiaque pares sunt. Dissimilis est rosa lilio, diuersus odor et tamen uterque flos alterum aequat. An non saepe uidisti duas puellas facie dissimili, sed ambas ea forma, ut excellentia factura sit ambiguum delectum, si cui detur optio. Non statim melius est, quod ad Ciceronis imaginem propius accedit, quemadmodum antea dicere coeperamus nullum animal omnibus membris propius ad hominis figuram accedere quam simiam, adeo ut, si uocem addidisset natura, homo uideri possit, nibil autem homini dissimilius esse quam pauum aut cygnum, et tamen cygnus, opinor, aut paus esse malles quam simius. ${ }^{30}$ (Cic. 184, 1073-1076).

Cícero é único e, portanto, não está em parte alguma "senão em si mesmo". Aquele que tiver a pretensão de reproduzi-lo não poderá exercer a autoexpressão, o que necessariamente torna seu discurso "um espelho enganoso" (mendax speculum).

\section{Longueil E O CATÁlogo de AUTORES}

Mas há ainda outra questão: mesmo que a eloquência de Cícero fosse imitável no sentido ciceroniano, "que uso tem hoje em dia (hodie quis est illius usus)?". A oratória de Túlio, que lhe foi tão útil no tribunal e no fórum, hoje já não caberia em nenhuma dessas situações. E, de qualquer forma, ainda que as causas fossem apresentadas em latim, "quem suportaria Cícero perorando os discursos que pronunciou contra Verres, contra Catilina, contra Clódio, contra o testemunho de Vatínio?" (quis ferret Ciceronem ea perorantem quae dixit in Verrem, in Catilinam, in Clodium, in Vatinium testem?).

${ }^{30}$ Que há de mais dessemelhante que uma esmeralda e um rubi? E, no entanto, são iguais no preço e na elegância. Dessemelhante é a rosa do lírio, diverso seu perfume, e, no entanto, cada uma destas duas flores iguala a outra. Acaso não viste às vezes duas meninas de rosto diferente, mas ambas de tal beleza que sua excelência haveria de tornar incerta a eleição, se a alguém fosse dado escolher? Como antes havíamos começado a dizer, aquele que chega mais perto da imagem de Cícero não é automaticamente melhor. Nenhum animal está mais próximo da figura humana em todos os membros do que o macaco, a tal ponto que, se a natureza lhe houvesse acrescentado a voz, poderia parecer um homem; não há nada, porém, mais dessemelhante ao homem do que um pavão ou um cisne, e, no entanto, preferirias ser um cisne, creio, ou um pavão, a ser um macaco. 
Itaque cui tandem usui paramus hanc operosam Ciceronis eloquentiam? Num contionibus? Vulgus Ciceronis linguam non intelligit et apud populum nibil agitur de re publica. Sacris uero contionibus minime congruit hoc dicendi genus. Quis igitur superest usus, nisi forte in legationibus, quae Romae praesertim Latine peraguntur ex more magis quam ex animo et magnificentiae causa potius quam utilitatis gratia. In his enim fere nibil agitur rei seriae; in laudibus eius ad quem mitteris, in testificatione beneuolentiae illius a quo mitteris et in locis quibusdam uulgaribus consumitur omnis oratio. Quid multis? Totum hoc eius generis est, ut rem magnam praestiteris, si speciem adulationis uitaris, cum ipsam adulationem non liceat. Frigidus etiam est, quod huic ex more respondetur, interdum non sine graui taedio prolixae dictionis, non nunquam et pudore illius qui laudatur immodice, saepe dicentis non pudore tantum sed et periculo, dum sudat recitans quae edidicit, dum haeret, dura sibi aliquoties excidit uel obliuione uel animi perturbatione. Quid autem admirationis habeant tales orationes, cum fere, qui recitat, ab rhetore quopiam elaboratam edidicerit, ut ad oratorem nostrum nibil redeat laudis praeter recitandi fortitudinem? Hic itaque praeter salutationis officium nibil agitur, quod est serium, priuatim literis et Gallicis colloquiis peragitur. Quod igitur theatrum petet noster Ciceronianus? Scribet epistulas Ciceronianas. Ad quos? Ad eruditos. Paucissimi sunt et hi nibil morantur Ciceronianam phrasim, modo sit sana prudens munda doctaque oratio. Ad quos igitur? ${ }^{31}$ (Cic. 208, 1196 a 210, 1212).

A partir de então, uma grande parte do diálogo consiste em apresentar uma imensa lista de escritores, da época de Cícero ao século XVI. Como um avesso do Brutus de Cícero, Buléforo vai apresentando um catálogo de oradores e escritores a Nosópono, para que este responda se cada um deles era ciceroniano ou não. De Quinto Cúrcio a Petrarca, de Cipriano a Lorenzo Valla, de Agostinho a Pico della Mirandola, de Sêneca a Aretino, dezesseis séculos de escritores

${ }^{31}$ Sendo assim, para que uso, afinal, preparamos esta laboriosa eloquência de Cícero? Para as assembleias? O vulgo não entende a língua de Cícero e não se tratam questões de Estado diante do povo. Mas este gênero de discurso não condiz com as assembleias sacras. Logo, que uso resta, senão talvez nas missões diplomáticas, que, sobretudo em Roma, são realizadas em latim, mas mais por costume do que por desejo, mais por pompa do que por utilidade? Pois nelas quase nenhum assunto sério é tratado: o discurso todo é consumido nos louvores daquele perante o qual és enviado, no testemunho da benevolência daquele pelo qual és enviado e em alguns lugares comuns. Para que dizer mais? Tudo isso é de tal gênero que farás uma grande coisa se evitares a aparência de adulação, uma vez que não se pode evitar a própria adulação. $\mathrm{E}$ o que costumeiramente se responde a isso é frio, às vezes não sem o pesado tédio de um discurso prolixo, por vezes também vergonhoso para aquele que é louvado desmedidamente; e muitas vezes não só vergonhoso mas até perigoso para aquele que fala, quando sua ao recitar o que aprendeu de memória, quando fica imóvel, quando sai às vezes de si mesmo, ou por esquecimento, ou por perturbação do espírito. Que têm de admirável tais discursos, quando aquele que os recita em geral somente aprendera de memória o discurso elaborado por algum rétor, de tal forma que a nosso orador não lhe resta outro mérito além do esforço de recitá-lo? [...] Então, que plateia buscará nosso ciceroniano? Escreverá cartas ciceronianas? Para quem? Para os eruditos. Mas são pouquíssimos e não lhes interessa em nada o estilo ciceroniano, contanto que o discurso seja correto, prudente, límpido e douto. Para quem, pois? 
passam pelo crivo de Nosópono, que nega a cada um deles o estilo ciceroniano, mesmo a Bembo, e só o concede a Longueil, e ainda assim com reservas. O nome do próprio Erasmo figura nessa lista:

(Bulephorus) Hinc tibi proferam Erasmum Roterodamum, si pateris.

(Nosoponus) Professus es te de scriptoribus dicturum. Istum uero ne inter scriptores quidem pono, tantum abest ut Ciceronianis annumerem.

(Bulephorus) Quid ego audio? Atqui uidebatur et inter polugraphous censeri posse.

(Nosoponus) Potest, si polugraphos est, qui multum chartarum oblinit atramento. Alia res est scribere, quo de nos agimus, et aliud scriptorum genus. Alioqui qui manu describendis libris quaestum faciunt, scriptores dicentur, cum hos eruditi malint librarios dicere. At hoc est nobis scribere, quod agro fructum producere, hoc nobis lectio quod agro stercoratio, hoc nobis concoctio et emendatio quod in agris occatio pastinatio putatio zizaniorum euulsio ac reliquae operae sine quibus aut non emergit sementis aut non adolescit exorta.

(Bulephorus) Quid igitur ille?

(Nosoponus) Abicit ac praecipitat omnia nec parit, sed abortit, interdum iustum uolumen scribit "stans pede in uno" nec unquam potest imperare animo suo, ut uel semel relegat quod scripsit, nec aliud quam scribit, cum post diutinam lectionem demum ad calamum sit ueniendum idque raro. Quid quod ne affectat quidem Tulliano more dicere, non abstinens a uocibus theologicis, interim ne a sordidis quidem?232 (Cic. 274, 1583 a 276, 1594).

Mas Erasmo não se furtou a dar uma última estocada em seus detratores: quando Nosópono diz que os italianos elogiam os escritos de Longueil, Buléforo responde: "louvam aqueles escritos, mas leem estes outros" (laudant illa, sed ista legunt). As "bagatelas de um orador batavo, chamadas de Colóquios" (Bataui oratoris naenias, quae Colloquia uocantur) são mais lidas que os escritos de

${ }^{32}$ BULÉFORO. De lá citar-te-ei Erasmo de Rotterdam, se mo permites. NOSÓPONO: Disseste que haverias de falar de escritores. Este, porém, nem sequer o ponho entre os escritores. Era só o que me faltava, incluí-lo entre os ciceronianos! BULÉFORO: Que ouço? Mas se me parecia até que poderia ser incluído entre os polygraphous! NOSÓPONO: É possível, se polygraphous é quem emporcalha muitos papéis com tinta preta. Uma coisa é escrever, tema de que tratamos, e outra o gênero dos escritores. Se não fosse assim, aqueles que ganham dinheiro copiando livros à mão seriam chamados de "escritores", quando os eruditos preferem chamá-los de "escribas". Mas, para nós, escrever é o que é para o campo produzir frutos; para nós, a leitura é o mesmo que a adubação para o campo; para nós, a reflexão e a correção é o mesmo que nos campos a gradagem, a lavragem, a poda, a arrancadura da cizânia e outros trabalhos sem os quais a semente ou não brota, ou, tendo brotado, não cresce.

BULÉFORO: Que achas, pois, de Erasmo?

NOSÓPONO: Ele joga tudo precipitadamente; não dá a luz, mas aborta; às vezes escreve um volume aceitável "apoiando-se num pé só”, mas nunca é capaz de ordenar a seu espírito que releia, ainda que uma vez só, o que escreveu, e não faz outra coisa que não seja escrever, quando deveria tomar da pena no final, depois de uma longa leitura, e mesmo assim raramente. Que dizer do fato de que nem sequer aspira a falar à maneira tuliana, não se abstendo de palavras teológicas e às vezes nem mesmo das vulgares? 
Longueil, "por mais elaborados, por mais polidos, por mais tulianos que estes sejam" (quamlibet eloborata, quamlibet expolita, quamlibet Tulliana). E a razão disso é que, nos Colóquios, o próprio tema seduz e entretém (capit moraturque) o leitor, ao passo que, nos escritos de Longueil, que são "teatrais e carecem de vida" (theatrica sunt et uita carent), o leitor "dorme e ronca" (dormitat lector stertitque).

A conclusão a que se chega depois de um verdadeiro desfile de praticamente todos os nomes da literatura em língua latina, de Cícero a Erasmo, é que nenhum deles, nem um sequer, conseguiu chegar a ser ciceroniano. Longueil, reconhecido pelos italianos como aquele que mais se aproximou de tal feito, jamais poderia atingir sua meta de ser um ciceroniano tal como os italianos o desejavam, pois nem sua condição nem suas ocupações foram idênticas às de Cícero, e, sendo assim, sua imitação não poderia ser senão inútil.

Quod genus sit: M-Tullius senator et uir consularis scribit ad suae dignitatis bomines, quid moliantur duces in prouinciis, quam instructae sint legiones, ostendit periculum, diuinat rerum exitum; cum ad imitationem Ciceronis similia scribit ad eruditos amicos et in otio uiuentes Longolius ueluti sollicitus de summa rerum, nonne friget affectatio? Quid? Quod ipse in museum abditus interdum literis mandat uanissimos rumores, quales uulgo circumuolitant, indigni qui uel sermone cordati hominis commemorentur?33 (Cic. 296, 1693-1694).

Os discursos de Longueil, "elaborados durante tantos anos, tantas vezes polidos na bigorna, tantas vezes oferecidos à censura dos críticos" (tot annis elaboratae, toties sub incudem reuocatae, toties criticorum censuram perpessae), bem pouco de Cícero têm. E "não por culpa de Longueil, realmente, mas dos tempos" (non quidem Longolii culpa, sed temporum).

Aptissime dicebat Cicero, uix apte Longolius, quandoquidem Romae nec patres conscripti sunt bodie nec senatus nec populi auctoritas nec tribuum suffragia nec magistratus, qui solebant esse, nec leges nec comitia nec actionum forma nec prouinciae nec municipia socii ciues; postremo Roma Roma non est nibil habens praeter ruinas ruderaque priscae calamitatis cicatrices ac uestigia. ${ }^{34}$ (Cic. 296, 1701)

${ }^{33}$ Por exemplo: Marco Túlio, senador e cônsul, escreve a homens de posição igual à sua, conta o que os generais realizaram nas províncias e quão armadas estão as legiões; aponta os perigos e pressagia o final dos acontecimentos. Quando Longueil, para imitar Cícero, escreve sobre coisas semelhantes a seus amigos eruditos, que vivem no ócio, como se estivesse preocupado com o assunto mais importante, acaso não é fria sua afetação? E que me dizes do fato de que ele mesmo, retirado em sua biblioteca, mande às vezes em suas cartas os rumores mais vãos, os quais circulam entre o vulgo, indignos de ser mencionados mesmo numa conversa casual de um homem sensato?

34 Cícero falava da forma mais apropriada; Longueil dificilmente poderia fazê-lo apropriadamente, uma vez que hoje em dia não há em Roma nem pais conscriptos, nem senado, nem a autoridade do povo, nem os sufrágios das tribos, nem os magistrados que 
É aqui também que Erasmo menciona a "contenda" (contentio) de Longueil com "certo jovem italiano" (cum Italo quodam adulescente), na verdade Celso Mellini, que elaborou a acusação formal contra o cisalpino quando este, "ainda que bárbaro por nascimento" (natione barbaro), pleiteou a cidadania romana. Segundo Erasmo, Mellini havia recebido a incumbência de "resgatar dos bárbaros" (a barbaris uindicaret) a eloquência ciceroniana. Uma das razões para isso era o preconceito dos italianos, que, julgando-se donos da eloquência e, sendo ociosos (otiosi) que "têm mais literatura do que religião" (qui plus habent literaturae quam pietatis), formaram uma "confraria" (sodalitas); outro motivo era a associação dos homens do norte com Lutero, "por culpa do qual o que quer que estivesse relacionado à Alemanha, para não dizer a todos os cisalpinos, tinha má reputação entre os romanos" (Lutheri causa, cuius gratia apud Romanos male audiebat quicquid erat affine Germaniae, ne dicam Cisalpini omnes).

Todo esse episódio foi, de fato, anedótico. Tendo solicitado cidadania romana (a qual Erasmo considera inferior à cidadania de Basileia), Longueil foi submetido pelos ciceronianos a uma espécie de tribunal em seu Capitólio, que Erasmo descreve como "uma espécie de salão não muito luxuoso, no qual meninos costumam representar comédias, a fim de exercitar seus talentos" (curiam quandam non admodum magnificam, in qua solent agi per pueros exercitandi ingenii gratia fabulae). Foi então apresentado contra ele um discurso preparado por Mellini, no qual era acusado de, num exercício de retórica de sua juventude, ter equiparado a França à Itália, e de haver mesmo ousado elogiar Erasmo e Budè, como "um bárbaro a outros bárbaros" (barbarus barbaros), e até de que havia sido subornado (subornatus) para levar consigo alguns livros italianos para os bárbaros, "com a finalidade de que estes pudessem rivalizar com os italianos pela primazia da cultura" (quo possent cum Italis de principatu eruditionis contendere); e, enfim, "que um homem bárbaro e de família obscura não parecia digno da honra de um título tão grande quanto o de ser chamado cidadão romano" (homo barbarus et obscurae familiae minime dignus uideretur honore tanti cognominis, ut ciuis Romanus appellaretur).

Atqui hoc plane ludicrum ille plus quam serio agit mirifico sane uerborum apparatu, magna ingenii significatione, summa uehementia, multa interdum urbanitate, non aliter alludens ad aetatem Ciceronis quam is, qui scripsit Batrachomyomachiam, allusit ad Homericam Iliadem, ranis ac muribus rebusque ridiculis ac friuolis deorum dearum heroum splendida uerba factaque accommodans; ita Longolius exaggerat capitis discrimen, armatas cohortes, gladiatorum manum quorum uiolentia auctoritas amplissimi ordinis ac secundem leges agendi libertas fuerit impedita. Fingit priscam illam Romam orbis reginam et huius praesidem ac tutorem Romulum cum suis Quiritibus, somniat patres

costumavam haver, nem leis, nem comícios, nem fórmulas processuais, nem províncias, nem municípios, nem aliados, nem cidadãos; enfim, Roma já não é Roma, e não tem nada além de ruínas e escombros, cicatrizes e vestígios de sua antiga queda. 
conscriptos et augustissimum ordinem regnorum dominum, populum in suos ordines ac tribos distinctum, praetorum ius, tribunorum intercessionem, somniat prouincias colonias municipia et socios urbis septicollis, recitatur senatus consultum, citantur leges; mirer non meminisse clepsydrarum quae reo solent infundi, nouem, opinor. Hic excitantur illa pathe, apellantur ueteres illi Romanae ciuitatis principes eque monumentis excitantur, quid non? Perquam faceta res est. ${ }^{35}$ (Cic. 302, 1722 a 304, 1725).

Tudo isso seria até divertido, diz, se fosse tomado como declamatio ou progymnasmata ou epideixeis, ou seja, como exercícios escolares, simulacros de discursos reais. Longueil, porém, levou a coisa a sério, e tanto se empenhou e esforçou nessa tarefa que veio a falecer prematuramente. Aqui, Erasmo tampouco se furtou a uma maldadezinha irônica que trai o quanto havia sido ofendido pelos comentários do círculo dos ciceronianos. É que ele diz que a morte prematura do brabante veio a seu favor; se tivesse vivido um pouco mais, poderia ter descoberto alguma outra coisa que não Cícero...

Gratulandum arbitror illius felicitati, qui suo tempore decesserit, priusquam banc gloriam aliqua nubecula offuscaret uel ob Graecarum literarum studium, cui se dicare coeperat, uel ex Christianis auctoribus oborta nebula, a quibus fortasse non satis constanter abstinuisset, si diuturnior uita contigisset. ${ }^{36}$ (Cic. 12, 101).

\section{A imitação de Cícero segundo Erasmo}

Erasmo passa então a explicar sua teoria da imitação. O primeiro ponto é extraído precisamente de Cícero: "o principal da arte é dissimular a arte" (De oratore 2.156, 177; Partitiones oratoriae, 19). Ora, então "um discurso que

${ }^{35}$ Mas Longueil tratou este assunto claramente risível de forma mais do que séria, com um mirífico aparato de palavras, com grande exibição de talento, com suma veemência e às vezes com muita elegância, aludindo à época de Cícero do mesmo modo que aquele que escreveu Batracomiomaquia aludiu à Ilíada de Homero, acomodando as palavras e feitos esplêndidos dos deuses, das deusas e dos heróis aos sapos e aos ratos e aos temas ridículos e frívolos. Assim, Longueil exagera os perigos de sua vida, as tropas armadas e a força dos gladiadores, por cuja violência se havia impedido a autoridade da ordem mais ilustre e a liberdade de agir segundo as leis. Ele imagina aquela bela Roma antiga, rainha do mundo, e seu chefe e protetor, Rômulo, com seus quírites; sonha com os pais conscriptos e com a augustíssima ordem dos senhores dos reinos, com o povo dividido em suas classes e suas tribos, com o direito dos pretores e a intercessão dos tribunos; sonha com as províncias, colônias, municípios e aliados da cidade de sete colinas; recita-se um decreto do senado, citam-se as leis; estranha-me que não se lembrasse das nove clepsidras que, creio, costumavam ser concedidas ao réu. Excita então as pathé, apela àqueles antigos heróis da cidade de Roma e os faz sair de seus monumentos; e o que não foi dito? A coisa toda é muito engraçada!

${ }^{36}$ Julgo que devemos dar-lhe congratulações pela felicidade de ter morrido no tempo certo, antes que alguma nuvenzinha ofuscasse essa glória, quer por causa do estudo das letras gregas, ao qual começara a dedicar-se, quer pelo aparecimento de uma nuvem a partir dos autores cristãos, dos quais talvez não tivesse se abstido tão completamente, se lhe tivesse tocado uma vida mais longa. 
entregou sua arte é frio, carece de credibilidade e é temido como algo insidioso" (friget enim et fide caret ac uelut insidiosa timetur). Aquele que nunca se afasta dos traços de Cícero, que, "com muito suor" (multo sudore) arranja as palavras, figuras e cadências (uerba figuras numeros) a partir dele, este será sempre incapaz de convencer de que "fala de coração" (ex animo), uma vez que seu esforço na imitação é tão visível. Este receberá apenas o elogio que obtêm "aqueles que escrevem centões" (centones). Se chegar a agradar a alguém, será "por pouco tempo" (paulisper), e somente "aos ociosos" (otiosos); seus discursos "nem ensinam, nem comovem, nem persuadem" (nec docent, nem mouent, nec persuadent). Em outras palavras, não cumprem nenhuma das três funções da retórica!

Em vez de violar a própria natureza e abandonar os modelos apropriados a fim de imitar Túlio mesmo quando este é infeliz em suas opções ou se mostra deficiente, Buléforo recomenda que seja imitado o seu exemplo, ou seja, que Arpinate seja imitado como ele mesmo havia imitado a outros:

An potius excussis Graecorum pariter ac Latinorum philosophis historicis rhetoribus comicis tragicis lyricis, demum ex omni scriptorum omnium genere suam illam diuinam phrasim collegit contexuit absoluit? ${ }^{37}$ (Cic. 86, 582).

Imitar à maneira ciceroniana é pois imitar como o próprio Cícero o fizera: não seguindo um modelo único, mas reproduzindo o mais conveniente de cada um dos autores principais.

Cicero scripsit animum Laelii spirare in scriptis illius. Stultum est autem hoc conari, ut alieno scribas stomacho desque operam, ut intuis scriptis spiret animus $M$-Tullii. Concoquendum est quod uaria diutinaque lectione deuoraris, meditatione traiciendum in uenas animi potius quam in memoriam aut indicem, ut omni pabulorum genere saginatum ingenium ex sese gignat orationem, quae non bunc aut illum florem frondem gramenue redoleat, sed indolem affectusque pectoris tui, ut, qui legit, non agnoscat fragmenta e Cicerone decerpta, sed imaginem mentis omni genere doctrinarum expletae. ${ }^{38}$ (Cic. 196, 1142-1145).

${ }^{37}$ Tendo examinado os filósofos, historiadores, rétores, poetas cômicos, trágicos e líricos, tanto dos gregos como dos latinos, recolheu, teceu e aperfeiçoou afinal aquela sua famosa elocução divina, nascida de todos os gêneros de todos os escritores.

${ }^{38}$ Cícero escreveu que a alma de Lélio respirava em seus escritos. Mas é tolo tentares escrever segundo o estômago alheio e prestares atenção para que a alma de Marco Túlio respire em teus escritos. Tudo o que tiveres devorado em leitura variada, é preciso digeri-lo e transportá-lo por meio do pensamento às veias do coração, mais do que à memória ou a um índice, para que o talento, cevado com todo tipo de pastos, gere de si mesmo um discurso que não tenha o cheiro desta ou daquela flor, folhagem ou relva, mas o da índole e dos afetos de teu coração, de forma que quem o lê não reconheça os fragmentos extraídos de Cícero, mas a imagem de uma mente repleta de todo tipo de ensinamento. 
Erasmo recorre então ao lugar-comum do imitador composto: como as abelhas, que colhem material de várias flores para, da soma de tudo aquilo que coletaram, formar algo novo, assim o imitador deveria recolher o melhor de variados modelos, para, assimilando-os, digerindo-os e transformando-os, criar algo novo.

Neminem priorum non legerat Cicero, quid quisque probandum aut reprehendendum haberet, diligenter expenderat, at neminem illorum proprie agnoscas in Cicerone, sed uim mentis ex omnium sententiis uegetatae. Si te parum mouet exemplum amasii tui, contemplemur exempla naturae. Apes num ex uno frutice colligunt mellificii materiam an potius ad omnes florum herbarum fruticum species mira sedulitate circumuolant, frequenter e longinquo petentes quod condant in aluearia? Nec statim mel est quod adferunt, fingunt ore uisceribusque suis liquorem ac in ipsas transformatum rursus ex sese gignunt, in quo non agnoscas nec floris nec fruticis delibati saporem odoremue, sed apiculae fetum ex omnibus illis temperatum. Iam nec iisdem frondibus pascuntur capellae, quo lac illis modo cognatum reddant, sed omni frondium genere saginantur; itaque non sucum herbarum, sed lac exillis transformatum referunt..$^{39}$ (Cic. 196, 1146 a 198, 1150).

Aceitar arcaísmos, palavras gregas, neologismos? A resposta erasmiana não poderia ser senão "por que não, se for bom?". No De copia, seu método para enriquecimento de todos os tipos de discurso por meio de todo tipo de variações, trata, em suma, de como dizer a mesma coisa de muitas formas diferentes, buscando a melhor expressão de si e segundo a conveniência. Não apenas traz um catálogo dos tropos e figuras de linguagem com exemplos extraídos de um vasto leque de autores como, dentre os exercícios propostos aos alunos, pedia que traduzissem (obviamente para o latim) os autores gregos, emulando-os e parafraseando-os, ou então que reescrevessem os poetas em prosa, ou, por outro lado, metrificar a prosa (cap. IX). O mesmo que Cícero havia feito.

Além disso, é impossível falar bem sobre um tema que se desconhece. Logo, a fonte da eloquência ciceroniana é "um coração ricamente instruído em um variado conhecimento de todos os temas" (pectus opulenter instructum uaria rerum omnium cognitione), "preparado com longa meditação nos preceitos da arte e em seguida na prática do escrever e do falar" (pectus artis praeceptionibus tum

${ }^{39}$ Acaso as abelhas colhem de um só broto a matéria para fazer o mel, ou antes voam com admirável dedicação ao redor de todas as espécies de flores, de ervas e brotos, vindo com frequência desde longe para procurar o que esconderão na colmeia? Nem é exatamente mel aquilo que transportam; com sua boca e suas vísceras formam um líquido e, tendo-o transformado dentro delas, geram de si mesmas um outro, no qual não reconhecerás nem o sabor nem o perfume da flor e dos brotos escolhidos, mas apenas o produto da abelhinha, preparado a partir de todos esses elementos. Nem as cabritas pastam nas mesmas folhagens a fim de produzir seu leite peculiar, mas alimentam-se de todo tipo de folhagens, e, assim, produzem não o sumo das ervas, mas sim o leite em que o transformaram. 
multo scribendi dicendique usu diutina meditatione praeparatum); e, principalmente, "um coração que ama aquilo que prega e que está cheio de ódio contra o que vitupera" (pectus amans ea quae praedicat, odio prosequens ea quae uituperat). Isso, no entanto, não é possível para "aqueles que não leem nada além de Cícero" (nibil legunt praeter Ciceronem).

Outra questão fundamental é que o estilo de Marco Túlio mesmo foi conveniente e adequado apenas a seu próprio tempo, e não teria agradado no século de Catão, o Censor. E mesmo na época de Cícero havia homens que ainda aspiravam àquela "antiga severidade" (priscam illam seueritatem), como Catão de Útica, Bruto e Asínio Polião, e estes reclamavam "algo de mais severo, menos teatral e mais viril na eloquência de Cícero" (seuerius quiddam, minus theatricum magisque masculum requirerent in Ciceronis eloquentia). Tanto menos adequado portanto será conveniente aos cristãos, "de cuja moral deve estar muito afastado tudo aquilo que se aproxima dos artifícios e do deleite teatral" (a quorum moribus oportet plurimum abesse quicquid ad fucos et scenicam delectationem).

Quid quod Cicero uarius est in dicendo? Alius est, cum sermone remisso placidoque docet philosophiam, alius in actionibus causarum, alius in epistulis, in quibus fere neglectus est et illaboratus sermo, atque hoc ipsum decet epistulam, quae in familiaris colloquii uicem successit. An non igitur praepostere fecerit qui ea cura conscribat epistulam de re familiari, qua Cicero meditatus est orationem pro Milone? ${ }^{240}$ (Cic. 212, 1227-1229).

Todos os argumentos encontram-se, em suma, subordinados a um somente, aquele que é o mais propriamente retórico: a saber, o decorum, ou seja, o conceito de cabimento, adaptação, conveniência. Erasmo defende o apte dicere contra a emulação simiesca dos ciceronianos italianos, ridicularizada em um comentário de Hipólogo: imaginar que a res é que deva se adaptar às preexistentes, predeterminadas e intocáveis uerba é "exatamente como se um grande artista fizesse roupas a partir de uma peça de joalheria, de anéis e pedras, e então forjasse uma estátua de cera em que esses ornamentos servissem, ou mesmo forjasse-a a fim de adaptá-la ao ornamento" (baud aliter quam si quis egregius artifex uestem praeclaram apparet, ad haec monilium, anulorum et gemmarum uim, mox ceream affingat statuam, cui baec accommodet ornamenta uel potius quam ad ipsa conflectat ornamenta)!

Finalmente, Erasmo faz uma referência à primeira grande batalha do ciceronianismo, aquela que se desenvolveu entre Cortesi e Poliziano, e toma

${ }^{40} \mathrm{E}$ que dizer do variegado que é Cícero ao falar? Quando ensina filosofia com uma linguagem prosaica e tranquila, é um; nas ações judiciais, outro; e outro nas cartas, nas quais sua linguagem é quase negligente e espontânea, e é isto mesmo o que convém à carta, que é a substituta de uma conversação entre amigos. Acaso não agiria às avessas aquele que escrevesse uma carta de tema doméstico com o mesmo cuidado com que Cícero meditou seu discurso Em Defesa de Milão? 
francamente o partido por este último. $\mathrm{Na}$ verdade, associa sua causa àquela de Poliziano e se identifica com ele. O ciceroniano Cortesi, diz, está muito mais afastado de Cícero que Poliziano, que "censura aqueles que mendigam de Cícero as palavras em caquinhos, que sempre seguem as pegadas alheias sem engendrar nada de si mesmos, que não fazem senão imitar e imitam somente palavrinhas" (ex Cicerone uerba frustillatim mendicant, qui semper alienis ingrediuntur uestigiis, cum nibil ex se gignant, qui nibil aliud quam imitantur et uerbula dumtaxat imitantur). Quanto à afirmação de Cortesi de que queria ser parecido com Cícero não como um símio se parece com um homem, mas como um filho se parece com o pai, Erasmo replica que o que ele faz é argumentar a favor da imitação simiesca.

Quanto a Marco Túlio, este é, segundo Buléforo, "o melhor artífice do discurso e até um homem bom" (dicendi artifex optimus atque etiam, uir bonus), considerando que se encontrava entre pagãos (ut inter ethnicos)... Mas a imitação servil deve ser evitada, uma vez que "aquele que sempre põe o pé na pegada alheia não pode caminhar bem, nem pode nadar bem jamais aquele que não se atreve a soltar a tábua" (non posse bene ambulare, qui pedem semper point in alieno uestigio, nec unquam bene natare, qui non audet abicere suber).

$\mathrm{E}$ isso por três motivos principais, que Buléforo recapitula: primeiro, "o estilo tuliano não vai bem para todos os talentos, a ponto de que tal afetação poderia acabar mal" (non quibuslibet ingeniis congruit Tulliana phrasis, ut male cessura sit affectatio); segundo, "se te faltam as forças naturais para que alcances uma facilidade oratória inimitável, que há de mais tolo do que te atormentares com aquilo que não se podes conseguir?” (si desunt naturae uires, ut inimitabilem dicendi felicitatem assequaris, quid stultius quam in eo discruciari, quod non potest contingere?); terceiro, "o estilo tuliano não convém a qualquer matéria nem a todas as pessoas" (ad haec nec materiae cuiuis nec personis omnibus congruit Tulliana phrasis), mas, ainda que conviesse, "vale mais a pena negligenciar certos aspectos que pagá-los caro demais" (si congrueret, quaedam negligere praestat quam nimio parare). E esse preço sai caro demais novamente por três motivos: "paga-se caro demais por aquilo que se compra com tanto dispêndio de tempo, de saúde e até da vida" (nimio uero paratur, quod tanto aetatis ualetudinis ac uitae etiam dispendio emitur); "por aquilo por cuja causa negligenciamos as disciplinas mais necessárias ao conhecimento" (nimio paratur, cuius gratia disciplinas cognitu magis necessarias negligimus); e enfim, por aquilo que se compra "à custa da piedade" (denique nimio paratur, quod pietatis iactura emitur). A questão é portanto estilística, filosófica e religiosa.

Mas há mais uma razão, que não poderia ser mais prática. É que se a eloquência é estudada precisamente para que "nossos escritos se desgastem nas mãos dos homens" (ut scripta mostra terantur manibus hominum), ou seja, para que os livros sejam constantemente manuseados, precisamente por isso deve-se "buscar com a arte a variedade que remediasse o estômago nauseado do leitor" (arte uarietas esset affectanda, quae lectoris nauseante stomacho mederetur), pois "a 
variedade tem tanta força nas coisas humanas que não convém usar sempre nem sequer as melhores coisas" (tantam uim habet in rebus humanis uarietas, ut nec optimis semper expediat uti).

A uniformidade é estranha à natureza e, portanto, também deve sê-lo ao estilo, uma vez que, de novo, o estilo é "o espelho da alma" (orationem esse speculum animi). O que o leitor busca ao ler é o deleite, e este advém da apreensão da singularidade do autor; aos leitores apraz "conhecer os afetos, o temperamento, a sensibilidade e o talento do escritor a partir do discurso" (ex oratione scriptoris affectus indolem sensum ingeniumque cognoscere), exatamente "como se tivesse tido trato com ele por muitos anos", (nibilo minus quam si complures anos cum illo consuetudinem egeris).

Et hinc diuersorum tam diuersa erga librorum scriptores studia, prout quenque genius cognatus aut alienus uel conciliat uel abducit, haud aliter quam in formis corporum alia species alium delectat offenditue. ${ }^{41}$ (Cic. 328, 1856).

E não apenas cada autor carrega em si sua particularidade, mas também cada leitor. O número de combinações possíveis entre todas as variáveis, considerando-se ainda os temas, as circunstâncias, a ocasião etc, é infinito. Por isso Erasmo afirma coerentemente, no decorrer de toda a sua obra, que a vida é variegada e transitória, e a diversidade dos objetos exige variedade do dizer, e que um conceito que fosse universalmente válido deixaria escapar o real, o qual é sempre singular. $O$ leitor não se afeiçoa a um autor porque este é capaz de recortar e colar a partir de um modelo consagrado a fim de exibir sua técnica, mas porque entre quem escreve e quem lê opera-se uma espécie de encontro (ou, como Giordano Bruno dirá décadas depois, de "vínculo"), e este se dá por afinidades eletivas, inclusive entre o imitador e o modelo, da mesma forma que entre o assunto e o orador. Poder escolher é aquilo que é o mais próprio do homem, no sentido humanístico da palavra.

Por isso, a conclusão de Buléforo é a teoria da imitatio de Erasmo:

Amplector imitationem, sed quae adiuuet naturam, non uiolet, quae corrigat illius dotes, non obruat; probo imitationem, sed ad exemplum ingenio tuo congruens aut certe non repugnans, ne uideare cum gigantibus theomachein. Rursus imitationem probo non uni addictam praescripto, a cuius lineis non ausit discedere, sed ex omnibus auctoribus aut certe praestantissimis, quod in quoque praecellit maxime tuoque congruit ingenio, decerpentem nec statim attexentem orationi quicquid occurrit

${ }^{41}$ Daí surgem interesses tão diferentes perante os escritores de livros diferentes, conforme um se compatibilize com um gênio semelhante ao seu ou se afaste de um diferente; não de outra forma que, com respeito às formas dos corpos, uma aparência agrada a um e outra desgosta a outro. 
bellum, sed in ipsum animum uelut in stomachum traicientem, ut transfusum in uenas ex ingenio tuo natum, non aliunde emendicatum esse uideatur ac mentis naturaeque tuae uigorem et indolem spiret, ut, qui legit, non agnoscat emblema Ciceroni detractum, sed fetum e tuo natum cerebro, quemadmodum Palladem aiunt e cerebro Iouis uiuam parentis imaginem referentem, nec oratio tua cento quispiam uideatur aut opus musaicum, sed spirans imago tui pectoris aut amnis e fonte cordis tui promanans. Sit autem prima praecipuaque cura cognoscendae rei, quam tractandam suscipis. Ea tibi suppeditabit orationis copiam, suppeditabit affectos ueros ac natiuos. Ita demum fiet, ut tua uiuat spiret agat moueat et rapiat oratio teque totum exprimat. ${ }^{42}$ (Cic. 332, 1899 a 334, 1873).

$\mathrm{O}$ discurso dos ciceronianos, quanto mais parecido com aquele que em Túlio foi tão eficaz e poderoso, mais indecoroso e inepto. Pois indecorum est affectare, quae nobis non congruunt. Ineptum est aliter uelle dicere quam res postulat.

Certamente um ouvinte mais atento, dócil e benevolente que Longueil, Nosópono é derrotado neste debate, o que, neste diálogo que havia começado com os sintomas de sua doença, significa que ele foi curado, e o foi por seu próprio veneno. As linhas finais do tratado retomam portanto o campo semântico das afecções, mas agora curadas por um grande médico, o Dr. Logos, e seu infalível antídoto: a eloquência ciceroniana.

\section{Comentários Finais}

Em sua introdução à tradução francesa de O Elogio da Loucura, Margolin (2010, p. 9) afirma que há duas palavras que nos servem de "fio de Ariadne" quando tentamos seguir as pistas deixadas por Erasmo: varietas e decorum. Ambas são palavras extraídas do jargão técnico da Retórica, e ambas são virtudes do orador. Se a principal qualidade de um orador é falar apropriadamente, é preciso

${ }^{42} \mathrm{Eu}$ abraço a imitação, mas aquela que ajudar a natureza, não a que a violar; a que corrigir os dotes naturais, não a que os destruir; aprovo a imitação, mas a que, conforme o exemplo, está de acordo com o teu talento ou que, ao menos, não se opõe a ele, para que não pareça um theomachein contra os gigantes. De novo, aprovo a imitação, mas não a dedicada a uma só prescrição, de cujos traços não se atreve a separar-se, mas aquela que, de todos os autores ou ao menos dos mais importantes, toma aquele que mais se destaca e o que mais se convém a teu próprio talento, colhendo e não acrescentando imediatamente ao discurso tudo de belo que se lhe apresente, mas fazendo-o passar a teu próprio coração, como se fosse ao estômago, para que, uma vez transfundido às veias, pareça nascido de teu próprio talento e não mendigado de outra parte. Inspirará assim o vigor e a índole de tua mente e de tua natureza, para que quem lê não reconheça o emblema tirado de Cícero, mas sim um feto nascido de teu cérebro, da mesma forma que, dizem, Palas saiu do cérebro de Júpiter, refletindo a imagem viva de seu pai, e teu discurso não pareça a ninguém um centão ou um mosaico, mas a imagem viva de teu peito ou um rio emanado da fonte de teu coração. Mas seja tua primeira e principal preocupação a de conhecer a matéria que te propões tratar. Ela te proverá copiosidade oratória, te proverá afetos verdadeiros e genuínos. Assim, enfim, dar-se-á que teu discurso viva, respire, aja, comova e arrebate, e reflita todo teu ser. 
ensinar que isso não é possível a menos que se considere o orador e seu discurso em relação com o público, o momento e as circunstâncias, caracteres e situações, diante dos quais o rétor terá de variar para "caber". Tudo em Erasmo convida à adaptação, segundo as circunstâncias naquele dado momento em particular.

Mas Erasmo não foi jamais um sofista, e sempre foi sua preocupação que a Retórica não viesse a degenerar em sofística, em palavras pelas palavras, em mentira. A sinceridade, entendida como correspondência entre discurso e vida, entre pensamento e expressão, é exigida, particularmente do cristão e ainda mais especialmente do pregador. Se é gravíssima a falta de harmonia entre o tipo de eloquência e o estilo e entre o discurso e o contexto, único erro capital é a falta de sintonia entre o homem e seu discurso. A fala é aqui speculum, expressão pessoal. Tudo aquilo que um homem é, pois, ele o revela por meio de sua fala.

Frequentemente criticado pelo aparente descuido e pela falta de revisão de seus textos, Erasmo parece reafirmar a todo momento que a forma é importante, mas não é dela que se trata. Não inteiramente, pelo menos. O que ele reafirmará a cada passo é que a linguagem deve ser a expressão sincera e consequente daquilo que há no interior da pessoa, precisamente porque o exterior deve necessariamente expressar o que vai pelo interior. Há, pois, correspondência entre vida e discurso.

Uma forma interessante de abordar a questão nos é dada pelo próprio Ciceroniano: em vez de escolher representar o sofista moderno com traços e gestos histriônicos, Erasmo escolhe pintá-lo com as feições do estudioso e esforçado Christophe de Longueil. Fumaroli (1980 : 101) o explica com a hipótese de que o holandês se interessa menos pelos traços e comportamentos exteriores da personagem do sofista (venalidade, oportunismo, vaidade, histrionismo) que por sua essência mesma: Nosópono-Longueil compartilha com os sofistas a mesma "doença", que consiste em erigir as uerba em ídolos e a esquecer as res divinas a que aquelas têm por tarefa servir e que devem significar. Assim, acrescentamos, o sofista erasmiano mente duplamente e, por assim dizer, tanto de dentro para fora quanto de fora para dentro: primeiro, porque suas palavras são descoladas da realidade e não a significam nem representam ; e, em seguida, porque seu discurso não expressa sua alma, mas antes tenta expressar, tola e falsamente, a de Cícero. O sofista erasmiano, Nosópono-Longueil, é aquele que vai negar sua própria natureza a ponto de vir a morrer jovem, em decorrência dos esforços gigantescos em prol de um ideal inalcançável.

Hipocrisia, comportamento dúplice e conduta dissimulada revelam aquilo que, para Erasmo, é o mais inaceitável : discrepância entre o discurso e a vida, fucus. Isso é a tal ponto central na obra deste filólogo que, para ele, a linguagem sequer pode ser considerada como tal se estiver " em desacordo com o espírito de onde provém" (si dissideat ab animo unde proficiscitur), e "não merece sequer o nome de linguagem" (ne orationis quidem meretur vocabulum), não mais que "a máscara não merece ser chamada rosto ou a pintura ser chamada carnação" (nibilo magis quam persona meretur dici facies, aut fucus hominis color) (LB V 772 F-773 A). 
O exemplo daquilo a que Erasmo chama Retórica é Paulo, que, "ao se acomodar a todos, é tão mutável que por vezes ele parece se opor a si mesmo e afirmar coisas contraditórias, enquanto ele é, em toda parte, perfeitamente coerente consigo mesmo" (denique dum omnibus sese accommodat, tam varius est, ut interdum videatur sibi contrarius, ac pugnantia loqui, quum sibi maxime constet undique) (LB $782 \mathrm{AB}$ ). Em contrapartida, o exemplo negativo é o arquétipo do ciceroniano, o qual, por produzir um discurso que almeja parecer de outrem, está necessariamente em desacordo consigo mesmo, está obrigatoriamente mentindo.

Frente a esses maus oradores e maus cristãos, Erasmo, chamado de barbarus, usa de ironia para consigo mesmo, dizendo-se polígrafo. Mas é que ele nunca cultuou a forma pela forma e, para ele, o melhor estilo não é aquele mais burilado ou mais bem acabado, ou aquele escrito em registro sublime, mas sim aquele que está de acordo com o íntimo do orador. O estilo deve casar com o pensamento e ser a expressão sincera de convicções, que não deve se curvar a um modo de expressão pré-estabelecido, sob pena de perder sua singularidade e sua originalidade. Cada homem é único; cada um deverá ter seu estilo, de acordo com as disposições naturais. O ciceroniano arrisca perder sua identidade, seu genius (palavra que aparece sete vezes no diálogo, segundo Chomarat, 1981, p. 833-4:). A uma moral do esforço, do trabalho, de uma eloquência ideal que não se adquire mesmo penosamente e à custa da saúde e da vida, como ocorreu com Longueil, Erasmo opõe a natureza, o talento inato que se pode aperfeiçoar, não contrariar (Magnien, 1999, p. 25). Sua busca jamais foi por um ideal irrealizável, que postulasse exigências acima das forças de cada um, para que todos coubessem em cânones pré-estabelecidos. Ao contrário, é a individualidade que deve ser preservada, porque ela é a garantia da sinceridade, dela depende a dicendi peritia. À pluralidade dos genii corresponde a pluralidade dos modelos, e por isso a incessante busca e defesa da varietas.

Aquilo que realmente importa transmitir não pode ser ensinado por preceitos que devem seguidos à risca e de forma servil, mas vem dos dons naturais (ingenium), de Minerva. Temos aqui, pois, que orador é aquele que sabe acomodar-se aos diferentes temas e circunstâncias, sem deixar de ser fiel a si mesmo e sem representar um papel que não lhe caiba. Por isso, em sua pedagogia, educar é possibilitar à criança a realização plena de sua natureza, e o melhor professor é aquele que é capaz de, respeitando a singularidade de cada um, favorecer a expansão do aluno até os limites de seus talentos e tendências. Esse respeito à singularidade e à diferença é, ao lado do elogio do prazer como método didático, a marca erasmiana. Parafraseando um passo bíblico, Erasmo parece dizer a todo momento que o estilo foi feito para o homem, não o contrário.

Contrariamente a seus detratores, que o acusavam de ser pouco esforçado e de jamais revisar suas obras, Erasmo prioriza não o esforço, mas o prazer ; não o trabalho laborioso de uma natureza refratária, mas a alacritas. Atuando a favor 
da natureza, aquilo que se faz para se aperfeiçoar, como ler e praticar, sequer é esforço ; se, no entanto, a imitação forçar a natureza para aquilo que ela rejeita, então o pobre aspirante à eloquência será torturado em vão. Da mesma forma, é inútil tentar imitar Cícero naquelas qualidades que, em tal medida e proporção, eram típicas dele, Cícero, e ninguém mais. Em outras palavras, tentar ser como Cícero é insano, inútil e impossível.

E, assim, chegamos a uma das mais importantes contribuições de Erasmo: a saber, o genius ou o talento inato, a pessoa ou personalidade do imitador e do modelo imitado. Ao aplicar as prescrições didáticas de Quintiliano às regras para imitação (a qual só é útil quando fortalece ou ajuda as disposições inatas, nunca quando as violenta), Erasmo acabou por introduzir o critério da subjetividade, tributário mas diferente do ethos da Oratória clássica. O orador erasmiano é aquele cuja escrita deve ser desde sempre a melhor forma de auto-expressão sincera, e, portanto, única, sem deixar de considerar o decorum que o torna atento à particularidade e à singularidade dos temas, das palavras, dos leitores, das circunstâncias.

Nesse ponto, Erasmo está sendo absolutamente moderno, prenunciando o discurso como originalidade e mesmo subjetividade, tal como essas questões vão surgir em Montaigne, por exemplo. Para o holandês, falar é uma questão de autenticidade pessoal, uma forma de auto-expressão que é sincera e, de qualquer forma, absolutamente pessoal, que revela conviç̧ões íntimas e posições pessoais, laços morais e religiosos.

Assim, a concepção erasmiana de imitatio se associa a seus preceitos sobre aquisição de copia e sua defesa da uarietas, mas estas não estão a serviço apenas do decorum devido às circunstâncias mas também, e talvez mesmo especialmente, servem a que o orador disponha de todas as formas possíveis de se expressar. Esta auto-expressão, porém, não é por assim dizer aleatória, mas vem, desde logo, associada à noção de que a expressão de um uir bonus é sempre e necessariamente verdadeira.

Que Erasmo considerasse que a expressão sincera e verdadeira passasse necessariamente por se exprimir em uma língua "estrangeira", o latim, é uma contradição que talvez demonstre a importância do Ciceroniano como tratado fundamental para a compreensão dos problemas, contradições e aporias da Retórica do século XVI. Como pano de fundo, temos o problema da permanência e da relevância da prática da língua latina por escritores na encruzilhada daquele momento em particular: de um lado, a recusa do latim "bárbaro" da Escolástica e a recuperação dos modelos do passado clássico nas línguas originais, e, do outro, uma crescente e já irreversível transição para as línguas vernáculas. E, ao mesmo tempo, trata-se da pertinência do emprego dos modelos clássicos para tratar de temas religiosos, tradicionalmente associados a uma "anti-retórica" cristã. Qual o significado e o sentido de imitar autores clássicos no século XVI e que era, então, apte dicere? Língua morta era o latim 
já restrito aos tratados filosóficos e teológicos e à correspondência dos membros da República das Letras ou o idioma tratado como objeto de dissecção dos ciceronianos? Ao escrever apenas e tão somente em latim, teria Erasmo sido o último nome de uma tradição já em vias de desaparecimento, ou terá sido ele, que zombou tão agudamente dos barbari e indocte docti escolásticos, o primeiro a perceber que o Medium Aevum que afastava seus contemporâneos da Antiguidade clássica com que se identificavam havia sido uma ruptura irreversível com os antigos tanto quanto a construção de um novo acervo para a inuentio? Teria ele se dado conta de que seu argumento anticiceroniano uideo mutata omnia ameaçava também a continuidade do latim como a língua da eloquência e minava a possibilidade da existência mesma do ideal de um "renascimento"? Além disso, o tratado satírico de Erasmo é também uma crítica mordaz à paganitas dos ciceronianos, que, não permitindo o uso de quaisquer palavras ou construções sintáticas que não pudessem ser encontradas no orador romano, colocavam todo o léxico cristão sob veto. Erasmo foi o autor em que todos esses problemas se encontraram e potencializaram, de tal forma que, por seu intermédio, podemos traçar um mapa tanto dos preceitos quanto das contradições da Retórica em sua época.

Em sua concepção, são os ciceronianos que fazem do latim uma língua morta. Aqueles que se autoproclamam ciceronianos, portanto, são anti-Cícero e aqueles que dão prioridade à elocução e decretam um modelo único e exclusivo como parâmetro para oradores que já desde há muito não falam latim como língua nativa, estes, em suma, são os que matam uma língua de cuja pujança a adaptação ao novo era a prova cabal. E, de fato, a construção da imagem de Nosópono é repleta de minúcias aparentemente gratuitas, mas que se revelam significativas quando se pensa na tarefa de um imitador como ele como se fosse um taxidermista ou um legista realizando uma necropsia. Pois só quando o objeto não está vivo é possível lidar com um corpus da forma como ele o faz, em silêncio, no meio da noite e tendo total controle sobre o material.

No entanto, a existência mesma do Ciceronianus nos mostra o quanto o processo de progressiva substituição do latim pelas línguas vernáculas era já considerável. Por isso, há mais em jogo aqui do que simplesmente uma teoria da imitação composta. A questão é tentar imaginar o quanto o próprio Erasmo tinha consciência de que sua defesa de um latim adaptado a todas as circunstâncias já era, ela mesma, ultrapassada. Uma questão interessante seria tentar imaginar o quanto Erasmo poderia estar ciente que não apenas o latim dos ciceronianos, mas mesmo o latim veicular, aquele que ele mesmo empregava e defendia, já não fazia sentido na vida pública. Embora ele nos tenha dado esses indícios claros de que tinha uma visão clara acerca de tudo o que estava em jogo, Erasmo não aprofunda a questão das línguas vernáculas. E, ao mesmo tempo, poder-se-ia dizer que sua tentativa de fazer do latim uma língua novamente viva, adaptada a todos os usos e práticas, esta sim é que deve ter parecido aos ciceronianos uma 
tentativa fracassada de voltar a Roma, mas uma Roma sem o que esta havia tido de mais alto.

É possível também imaginar que foi ele quem menos entendeu a emergência da escrita em línguas vernáculas escritas, inclusive como novo meio de propaganda, o qual, possibilitado pela prensa de Gutenberg, viria a alimentar a Reforma com traduções da Bíblia e panfletos contra o papa em alemão. Mas Erasmo foi o autor mais lido do século XVI, e seus manuais e obras de referência, de retórica ou teologia, tiveram na época tanto sucesso quanto seus tratados satíricos conhecidos até hoje, como O Elogio da Loucura. Não há autor do século XVI, inclusive em língua vernácula, que não deva ser estudado em relação à herança deixada por Erasmo, e não há adversário seu que consiga escapar à necessidade de ser conhecido em relação a ele. Nesse sentido, é ele, o batauus barbarus, o maior nome da língua latina no século XVI. De origem nada ilustre, Erasmo era, como Cícero, um homo nouus, alguém cujo poder advinha da palavra. O latim era sua casa, e, como era de sua natureza, ele quis convidar a todos a essa casa que era de todos. Diz Chomarat (1981, p. 821), no entanto, que "a tentativa de Erasmo de voltar a um latim realmente cotidiano", "um latim composto, adaptado a todas as necessidades modernas, de fato jamais falado antes", essa tentativa foi "audaciosa, admirável", mas "ela falhou"...

Emile Telle (1974, p. 95) afirma que, "um dia", quando a história do erasmismo for escrita, ela será representada em "um díptico, o pró e o contra”, e "o contra será mais significativo que o pró", pois, tendo atingido "uma primazia e uma autoridade tais" como jamais na "história espiritual do mundo ocidental", terminou, no entanto, sendo o retrato de um "mal entendido" e mesmo de um "dissabor amoroso", "de uma decepção e de arrependimentos trágicos para alguns”, e vários de seus discípulos e admiradores voltaram-se contra ele.

Com a crise gerada pela Reforma, as guerras religiosas, a Inquisição, a execução de Thomas More, e tendo percebido que os "romanos", que deveriam ser seus aliados contra a ameaça luterana, estavam, ao contrário, mais preocupados com a imitação ciceroniana, Erasmo deve ter se dado conta de que, de alguma forma, o mundo ao qual ele pertencia estava chegando ao fim, assim como a língua latina viva e ativa que ele defendia. Tivesse vivido alguns anos mais, teria chegado a ver seus textos incluídos no Index dos livros proibidos pela Igreja romana.

Cremos que o Ciceroniaus foi um dos mais poderosos catalisadores desse desapontamento de tantos para com o até então preceptor da Europa, que, pouco depois, morreu cercado de poucos amigos. Primeiro, porque o colocou em conflito aberto contra praticamente todos os humanistas de seu tempo; segundo, porque o ceticismo de Erasmo para com idealismos impossíveis, a que considerava tão inatingíveis quanto perigosos, certamente feriu a susceptibilidade de muitos, que teriam talvez preferido vê-lo contemporizar e ceder diante de um ideal, ainda que literário. Mas este inimigo do dogmatismo, que jamais aderiu a nada, 
permaneceu fiel a seu lema Concedo nulli. Tendo recusado o convite de Paulo III para ser cardeal e tendo abandonado sua posição de conselheiro de Carlos V, Erasmo renegou também uma auctoritas ainda maior e certamente mais exigente que estas duas: a de Cícero.

Mas ele o fez em latim, e apenas em latim. 


\section{REFERÊNCIAS BIBLIOGRÁFICAS}

ARMOUR, P. "The Comedy as a Text for Performance". In: BRAIDA, A. \& CALE, L. (ed.) Dante on view: The reception of Dante in the visual and performing arts. Hampshire: Ashgate Publishing Ltd., 2007.

BARRAL-BARON, Marie. L'enfer d'Érasme. L’humaniste chrétien face à l’histoire. Genève : Droz, 2014.

CAVE, T. The Cornucopian Text. Problems of writing in the French Renaissance. Oxford: Oxford University Press, 1985.

CHOMARAT, J. Grammaire et rhétorique chez Érasme. Paris: Belles Lettres, 1984. $2 \mathrm{v}$.

CORNISH, A. Vernacular Translation in Dante's Italy. Illiterate Literature. Cambridge: Cambridge University Press, 2011.

DELLANEVA, J. (ed.) Ciceronian controversies. I Tatti Renaissance Library. Cambridge: Harvard University Press, 2007.

ÉRASME. Éloge de la folie et autres écrits. Collection Folio Classique. Édition de MARGOLIN, J.C.

ERASMO. Diálogo Ciceroniano. Trad. e notas Elaine C. Sartorelli. São Paulo: Levoir para a Folha de SP, 2015.

ERASMO DE ROTERDÃ. Diálogo Ciceroniano. Tradução, introdução e notas de E. C. Sartorelli. São Paulo: EDUNESP, 2013.

ERASMUS. Opera omnia i/2. Amsterdam, 1971.

. Dialogus Ciceronianus (latin edition). University of California Library, 1919 (reprinted).

FUMAROLI, Marc. L'Age de l'eloquence. Rhétorique et "res literária" de la Renaissance au seil de l'époque classique. Gèneve: Droz, 1996.

GAMBARO, A. Il ciceroniano o dello stilo megliore. Brescia: La Scuola, 1965.

JEANNERET, M. Perpetuum mobile. Métamorphoses des corps et des oeuvres, de Vinci à Montaigne. Paris: Macula, 1997.

LEVI, A. H. T. (ed.) Desiderius Erasmus. The Collect Works of Erasmus. Literary and Educational Writings. Edited by A. H. T. Levi. Toronto: University of Toronto Press, 1986. v. 6.

MACK, P. A History of Renaissance rhetoric. 1380-1620. Oxford: Oxford University Press, 2011.

MAGNIEN, Michel. "Un écho de la querele cicéronienne à la fin du XVIe. Siècle: éloquence et imitation dans les Essais”. In Rhétorique de Montaigne, ed. F. Lestringant, Paris, Champion, 1985, p. 85-99. 
MAÑAS NUÑEZ, M. El Ciceroniano. Madrid: Akal, 2009.

NAUERT, C. G. (ed.) Desiderius Erasmus. The correspondence of Erasmus. Letters 1658 to1801 (January 1526 - March 1527). Toronto / Buffalo / London: University of Toronto Press, 2003.

PEREIRA, B.F. Retórica e eloquência em Portugal na época do Renascimento. Lisboa: Imprensa Nacional-Casa da Moeda, 2012.

RUUD, J. Critical companion to Dante. A literary reference to his life and work. New York: Facts on File, 2008.

SCOTT, I. Controversies over the imitation of Cicero as a model for style and some phases of their influence on the schools of the Renaissance. New York: Columbia University, 1910.

SUZZONI, Cécilia (ed.). Érasme dans le XXIe. Siècle. Séductions d'une écriture. Paris : E. Kimé, 2012.

TELLE, E. V. L'Erasmianus siue Ciceronianus d'Etienne Dolet (1535). Introduction. Fac-similé de l'édition originale du De Imitatione Ciceroniana. Commentaires et appendices. Genève: Librairie Droz, 1974. 